\title{
Social Subsidies and Marketization - the Role of Gender and Skill*
}

\author{
Robert Duval-Hernández ${ }^{\dagger}$ \\ University of Cyprus, CIDE, and IZA \\ Lei Fang \\ Federal Reserve Bank of Atlanta \\ L. Rachel Ngai ${ }^{\S}$ \\ London School of Economics, CEPR, and CfM
}

February 14, 2018

\begin{abstract}
This paper decomposes the differences in aggregate market hours between US and Europe across gender-skill groups and finds that low-skilled women are the biggest contributors to aggregate differences, with the exception of Nordic countries. We develop a model to account for the gender-skill differences in market hours across countries. Taxes, which reduce market hours in favor of leisure and home production, explain a substantial fraction of the differences in hours for Southern and Central European countries. Subsidized family care, which reduces home hours of women in favor of market hours, explains the different pattern of hours in Nordic countries. Low-skilled women are more responsive to policy because of their comparative advantage in producing home services and the corresponding market substitutes.
\end{abstract}

JEL classification: E24, E62, J22

Keywords: Cross-country Differences in Market Hours, Home Production, Subsidies on Family Care

\footnotetext{
*We wish to thank Alessio Moro, Chris Pissarides, Michelle Rendall and Etienne Wasmer, as well as seminar participants at CIDE, ILO, and LSU, and conference participants at Midwest Macro meetings 2016, Econometric Society North America Summer meetings 2016, Conference on European Employment at the University of Cyprus 2016, Conference on Structural Transformation and Macroeconomic Dynamics at the University of Kent 2016, Conference on Growth and Development at Madrid 2017, Asian and China meetings of the Econometric Society 2017, the Society for Economic Dynamics meeting 2017, and Tsinghua Workshop in Macroeconomics 2017 for useful comments. The views in this paper represent those of the authors and are not those of either the Federal Reserve Bank of Atlanta or the Federal Reserve System. We acknowledge financial support from the European Research Council EUROEMP Advanced Grant (\#323940) administered by the University of Cyprus.

${ }^{\dagger}$ rduval@ucy.ac.cy, ${ }^{\ddagger}$ lei.fang@atl.frb.org, ${ }^{\S}$ L.Ngai@lse.ac.uk

${ }^{\S}$ Corresponding Author: Department of Economics, LSE, Houghton Street, London WC2A 2AE, UK
} 


\section{Introduction}

Aggregate hours of market work in broadly similar countries across the OECD vary widely. For example, during the early 2000s, weekly market hours per adult aged 20-64 in the U.S. were about 28 while they ranged from 19 to 25 in the European countries in our sample. While some of these differences can be attributed to a different demographic composition across countries along dimensions such as age, marital status, gender, and education, the majority of the differences are driven by responses of different demographic groups to different incentives in the labor market.

The objective of this paper is to delve deeper into the cross-country relationship between policies associated with the welfare state and the time allocation of different demographic groups. In particular, we study to what extent and for which population groups the effect of taxes on market hours can be offset by social subsidies on family care activities, such as child and elderly care, that are close substitutes to home production.

Using household surveys from 17 OECD countries, we analyze market hours by genderskill group and by sector, and document two important stylized facts. First, women without a college degree (hereafter, referred as low-skilled women) are the population group that contributes most to the cross-country differences in aggregate market hours, with the notable exception of Nordic countries. On average, $40 \%$ of the difference in aggregate market hours between non-Nordic European countries and the U.S. is accounted for by the hours of lowskilled women, and $60 \%$ by women in total; while in Nordic countries low-skilled women only account for one-fourth of the difference, while women in total account for about $40 \%{ }^{1}$ Second, there are also notable differences between the sectoral hours of Nordic and other European countries. In most Central and Southern European countries more than $40 \%$ of the aggregate difference in hours relative to the U.S. is accounted for by the service sector that produces close substitutes to home production. In Nordic countries in contrast, this fraction falls to one-third.

Large cross-country differences also exist in terms of policies on taxes and social subsidies. The U.S. has both low taxes and low subsidies. European countries in contrast, have high taxes and a large variation in the generosity of subsidies, with significantly high subsidies in Nordic countries.

Motivated by these stylized facts, we develop a multi-sector model to study the quantitative effects of social subsidies and taxes on market hours by gender-skill groups. The main idea is that social subsidies and taxes affect market hours differently across gender-

\footnotetext{
${ }^{1}$ Using harmonized time use surveys, Fang and McDaniel (2017) find that differences in cross-country market hours are dominated by the market hours of women.
} 
skill groups through two substitution margins: across market and home and across work (market plus home) and leisure. Because women provide most of the care both at home and in the market, subsidies to market substitutes of home care mainly affect female market hours, especially for low-skilled women. ${ }^{2}$ Taxes also affect the home and market margin, but in addition they alter the hours of all gender-skill groups through the substitution margin between work and leisure.

The model consists of three market sectors producing goods, non-substitutable services, and substitutable services. Substitutable services and home services are good substitutes, with an elasticity of substitution greater than one, while goods and services are poor substitutes. We model subsidies as a negative tax on the market consumption of services that are close substitutes to home production. There are four types of labor inputs, male and female with low or high skill. Production in each sector involves all four types of labor inputs. The representative household allocates time to market work, home production, and leisure for each gender-skill group.

The model is calibrated to match time allocation by gender, skill and sector in the U.S. economy. The observed sector-specific gender intensity implies that women (especially lowskilled women) have a comparative advantage in producing home and substitutable market services, while men have a relative comparative advantage in producing goods and nonsubstitutable services. ${ }^{3}$ We then feed in the taxes (income and consumption) and subsidies observed in European countries to make predictions for their market hours by gender-skill groups.

The combination of comparative advantages of production factors and preferences is critical in producing the model predictions. Specifically, higher social subsidies reduce the relative price of substitutable market services, and thus lower the cost to marketize home services and increase the demand for substitutable market services. This process of marketization shifts hours of work from home to the market, especially into the substitutable service sector. As women (especially low-skilled women) have a relative comparative advantage in producing home and substitutable services, they experience a larger increase in market hours relative to men. Lower taxes affect the home and market margin in a similar way, but they also operate through the work and leisure margin which increases the market hours of all demographic groups and sectors.

\footnotetext{
${ }^{2}$ Both Freeman and Schettkat (2005) and Burda, Hamermesh and Weil (2013) emphasize the importance of the substitution between home and market production in understanding cross-country differences in market hours.

${ }^{3}$ Further references on women's comparative advantage in services relative to men are, for example, Weinberg (2000) on interpersonal and communication skills; and Galor and Weil (1996) and Rendall (2017) on brain versus brawn skills.
} 
The quantitative results indicate that differences in taxes and social subsidies can account for a substantial fraction of the observed cross-country differences in market hours by gender, skill, and sector. On average, taxes alone can account for virtually all the differences in aggregate market hours between Central European countries, Canada and the U.S., and for $89 \%$ of the difference between Southern European countries and the United States. Nordic countries in contrast have higher taxes, but also higher female market hours than other European countries, and thus taxes alone cannot explain this pattern. Higher social subsidies in Nordic countries are key in accounting for their high female market hours, especially for the high hours of low-skilled women. As a result of the introduction of subsidies in the model, the correlation between the market hours predicted by the model and the data more than triples for low-skilled women, and it increases by more than $50 \%$ for the substitutable service sector. More generally, accounting for subsidies improves the model fit of aggregate market hours by $20 \%$.

Using harmonized time use data, we show that the model predictions on the two margins are consistent with the data. More specifically, taxes alone can account well for the time allocation between total work and leisure for both men and women, while subsidies significantly improve the model prediction on the time allocation of women between market work and home work.

Finally, the model predicts higher gender wage ratios (women relative to men) in European countries. This is a unique feature of the model that is consistent with the data. Quantitatively, however, taxes and subsidies fall short in accounting for the differences in gender wage ratios between European countries and the United States. This suggests that other complementary factors are important in determining the cross-country differences in gender pay gaps (see for instance Blau and Kahn (2000) and Blau and Kahn (2003)).

There is a large literature analyzing the relation between taxes and cross-country differences in aggregate market hours, beginning with the one-sector models of Prescott (2004) and Ohanian, Raffo and Rogerson (2008). Rogerson (2008), Olovsson (2009), McDaniel (2011) and Duernecker and Herrendorf (2018) argue that home production is important in propagating the effect of taxes.

The studies closest to ours are Ngai and Pissarides (2011) and Ragan (2013). By studying the impact of taxes and social subsidies on hours of work they find that subsidies play an important role in accounting for differences in aggregate market hours between European countries and the U.S., especially in Nordic countries. As in our paper, subsidies in these studies operate through the substitution between market and home work. However, none of these papers analyzes cross-country differences in market hours by demographic group. ${ }^{4}$

\footnotetext{
${ }^{4}$ Ngai and Pissarides (2011) study the distribution of work between different market sectors and home
} 
The importance of social subsidies on the labor supply of low-skilled women has also been documented by other papers in the literature. For instance, empirical micro studies have found that increasing the provision of government funded pre-school encourages women to work and the impact is concentrated among low-income women (Cattan 2016). Similarly, in the macro literature, Guner, Kaygusuz and Ventura (2017) show that increasing child-care subsidies in the U.S. has substantial positive effects on female labor supply, especially for lowskilled women. ${ }^{5}$ For adult care, Barczyk and Kredler (2018) documented that countries with low public spending on long-term care are less likely to use market-provided care services, and instead rely on care provided by family members, which is also consistent with our findings.

A complementary strand of the literature has focused on the structure of the tax system taking into account the role of gender and marital status. Chakraborty, Holter and Stepanchuk (2015) study the role of divorce and taxes and Bick and Fuchs-Schündeln (forthcoming) study the role of the non-linearity of labor income taxes in accounting for the cross-country differences in market hours by gender. In contrast to these two papers, we focus on the effect of social subsidies in lowering the cost of outsourcing home production. The distinction between home production and leisure as competing non-market activities enables us to analyze separately the adjustment of hours along the margin of total work and leisure and the margin of market work and home work. As we show, this distinction is important in understanding the effect of taxes and subsidies on gender and skill differences in market hours across countries. Rendall (forthcoming) separately analyzes home hours and leisure but her focus is different from ours, being the potential impact of different taxation regimes on the structural transformation and the rise of female and service employment in the United States.

The rest of the paper is organized as follows. Section 2 presents the cross-country facts that motivate the paper. Section 3 presents the model and provides intuition on the effects of taxes and subsides through the two margins. Section 4 calibrates the model and presents the quantitative results. Finally, section 5 concludes.

production, while Ragan (2013) studies the impact of policy on total hours worked in the market and at home.

${ }^{5}$ Hannusch (2018) finds that child-related transfers are important in accounting for the participation differences between married women with and without children. 


\section{Data and Cross-Country Facts}

Our data covers almost all the EU-15 region, plus Norway, Canada, and the United States for the years of 2000-2004. ${ }^{6}$ This section briefly describes the data used in the analysis and presents a set of key stylized facts. For a more detailed description of the data sources and construction procedures, please refer to the Data Appendix.

\section{$2.1 \quad$ Data}

\subsubsection{Market Hours}

Market hours are constructed using the standardized EU Labor Force Survey (EU-LFS) for European countries, the March Supplement of the Current Population Survey (CPS) for the United States, and the 2001 Population Census for Canada. The sample includes individuals between the ages of 20 and 64. The annual average hours worked per person are derived as the total annual hours divided by the number of individuals within the specified age range. Following procedures outlined by Bick, Brüggemann and Fuchs-Schündeln (2016), we construct consistent measures of annual hours worked per person across countries.

It is well-known that market hours differ across demographic groups. For instance, highskilled individuals work more than low-skilled individuals, prime-age individuals work more than young and old individuals, and married women work less than single women. It is therefore potentially important to control for differences in the demographic composition when making cross-country comparisons. Table A1 in the Data Appendix shows that differences in the demographic composition of the population (by gender, skill, age and marital status) account for $2-33 \%$ of the aggregate cross-country difference in market hours in our sample. Thus, cross-country differences in hours worked within the same demographic group explain most of the differences in aggregate market hours across countries.

To understand the effect of taxes and subsidies on each gender-skill group, estimates of market hours are constructed controlling for cross-country differences in demographic composition. Specifically, we partition each country's population according to skill, gender, age, and marital status, and calculate the average working hours for each group in this partition. The cell-specific averages are then aggregated into hours per person for each gender-skill group in each country using constant population shares constructed from the U.S. data. The population shares also control for differences in age and marital composition across gender-skill cells. Thus we control for differences in marriage rates across education groups and across countries.

\footnotetext{
${ }^{6}$ Of the EU-15 region, only Luxembourg is excluded as there is no comparable tax data.
} 
Table A2 checks for the impact of one additional partition of the population depending on the presence of small children in the household. The analysis excludes Nordic countries and Canada due to the lack of data. The resulting hours by gender-skill for the remaining 12 countries only change slightly relative to the ones obtained under the original partition. ${ }^{7}$ We abstract from this dimension in our data partition because one of our objectives is to understand the differences in market hours by gender and skill between Nordic countries and other European countries.

To study the implications of policy through the market and home margin, market hours are estimated for three sectors: goods, non-substitutable services, and substitutable services sectors. This is the simplest classification to capture the idea that men and women may have different comparative advantages in producing goods and services and the fact that only a subset of the service sector can be substituted with home production. Broadly speaking, a service industry is classified as "substitutable" if its product can be replaced by activities performed at home. To be consistent, in the construction of sectoral hours we also control for differences in the demographic composition across countries. ${ }^{8}$

\subsubsection{Time Allocation across Market, Home and Leisure}

To examine the two margins of substitution across work and leisure and across market and home, the share of market hours as a fraction of total work (market plus home), and the fraction of total work out of total time are constructed using the American Time Use Survey (ATUS) and the Multinational Time Use Study (MTUS). For the years we study, time use surveys are available for ten of the sample countries. ${ }^{9}$ The construction of market and home hours follows closely Aguiar and Hurst (2007b) with the key exception that we include child care in home hours. Leisure is any time not allocated to work neither in the market nor at home. These estimates are also adjusted for demographic composition differences following the procedure outlined earlier.

\footnotetext{
${ }^{7}$ There are two main reasons for the similarity in the results. First, the share of women with small children is on average only $18 \%$ in our sample. Second, this group works less than other demographic groups in every country, including the United States. Thus, they do not contribute much to aggregate cross-country differences in the working hours of women.

${ }^{8}$ The substitutable service sector includes Retail trade, Hotels and restaurants, Health and social work, Personal and community services, and Domestic services hired by households. Given the available industry classification in most household surveys it is not possible to do a more detailed disaggregation. The Data Appendix contains the detailed sector classification (Table A3), as well as a description on how we perform the adjustment for demographics in sectoral hours.

${ }^{9}$ The countries are Canada, Denmark, France, Germany, Italy, the Netherlands, Norway, Spain, the United Kingdom, and the United States.
} 


\subsubsection{Wages}

Hourly wage rates are constructed using various sources including the European Community Household Panel (ECHP) and the European Union Statistics on Income and Living Conditions (EU-SILC) for most countries, Labor Force Surveys for France and the UK, the Socioeconomic Panel (SOEP) for Germany, the 2001 population Census for Canada, and the March CPS for the US. Gender wage ratios for low-skilled and high-skilled are estimated after controlling for age and marital status through a standard Mincerian regression.

\subsubsection{Taxes and Social Subsidies}

Social subsidies on care are applicable only to the substitutable service sector. We include public "in-kind" expenditures (i.e. non-cash benefits) on old-age, incapacity, and family care services. The main care items covered include residential care, home-help services, rehabilitation, day-care, and early childhood education. The expenditures include direct expenses on the provision of these services, as well as subsidies for the purchase of such services in the market. The expenditure data comes from the OECD Social Expenditure Database (SOCX) (Adema, Fron and Ladaique 2011). Following Ngai and Pissarides (2011), the subsidy rate is computed by expressing expenditures as a fraction of the gross output of the substitutable service sector.

Because our main focus is on social subsidies, we abstract from the complexity of the tax structure and use average labor income and consumption taxes as constructed by McDaniel (2007). Average labor income taxes include Federal and State income taxes, as well as Social Security taxes.

The country-specific tax and subsidy rates are reported in Table A4. The constructed subsidy rates are much larger in Nordic countries than in other European countries and the United States. On average, $45 \%$ of the total expenditure on social subsidies is accounted for by old-age and incapacity benefits, and the number rises to almost $65 \%$ in Nordic countries. The rest is accounted for by other family benefits, such as day-care and early childhood education.

\subsection{Cross-Country Facts}

\subsubsection{Market Hours}

Table 1 presents weekly market hours per person. As reported in the literature, the U.S. has the highest weekly hours per person among the studied countries. In European countries 
weekly hours range between $72-92 \%$ of the hours in the United States. ${ }^{10}$ Among them, Italy has the lowest weekly hours.

Figure 1 presents the percentage difference in hours worked relative to the U.S. for each of the four population groups. In most countries the largest proportional differences occur for low-skilled women, and the differences are larger for women than for men with the same skill level. The main exception to this occurs in Nordic countries. ${ }^{11}$ On average, low-skilled women in non-Nordic countries work 30\% less in the market than their U.S. counterparts, while this difference is $20 \%$ for high-skilled women and $12-14 \%$ for men. However, in Nordic countries low-skilled women work only $15 \%$ less than their U.S. counterparts, and this difference is roughly similar for other gender-skill groups.

Columns 3-6 of Table 1 report the contribution of each demographic group to the difference in aggregate market hours with respect to the United States. In Central and Southern European countries on average $40 \%$ of the difference in market hours is accounted for by the hours of low-skilled women, and $60 \%$ by women in total. In contrast, in Nordic countries, Canada, and Portugal, low-skilled women only account for one-fifth of the difference, and women in total account for $40 \%$.

Turning now to the sectoral dimension, Figure 2 displays the proportional differences in sectoral hours relative to the United States. Consistent with Rogerson (2008), lower aggregate market hours are mostly due to lower hours in service sectors. In fact, a few European countries even have higher hours in the goods sector than the United States. Again, there are notable differences between the sectoral hours of Nordic and other European countries. On average in non-Nordic countries market hours are $26 \%$ lower in the service sector that produces close substitutes to home production. In Nordic countries in contrast, this number falls to $17 \%$. Columns $7-9$ of Table 1 report the contribution of each sector to the difference in aggregate market hours from the United States. In most Central and Southern European countries more than $40 \%$ of the aggregate difference is accounted for by the substitutable service sector; while in Nordic countries and Canada this fraction falls to one-third and one-fifth, respectively.

\subsubsection{Market Hours and Taxes}

The top panel in Table 2 reports the regressions of annual market hours per person for the four demographic groups against the subsidy rate and the effective tax rate. The effective

\footnotetext{
${ }^{10}$ We group Ireland together with Southern European countries based on the similarity of the labor supply of women among these countries.

${ }^{11}$ Canada and Portugal are also exceptions.
} 
tax rate, as in Prescott (2004), is

$$
\frac{\text { consumption tax rate }+ \text { labor income tax rate }}{1+\text { consumption tax rate }} .
$$

The regressions show that higher subsidies are associated with higher female market hours, especially for low-skilled women; while they are not correlated with male market hours. In contrast, higher taxes are associated with lower market hours for all demographic groups. Moreover, after controlling for the impact of subsidies, the tax effect increases significantly for women, and more than doubles for low-skilled women; while there is no significant change for men. ${ }^{12}$ This suggests that subsidies are an important driving force for female market hours, but not for male market hours.

Figure 3 plots sectoral hours against taxes. The tax rate for goods and non-substitutable services is the same as the effective tax rate defined earlier. For the substitutable service sector we present the correlations of market hours with the effective tax rate, as well as with the effective tax rate net of the subsidy rate. The figure shows that market hours in all the three sectors are negatively correlated with taxes, and that the largest negative association occurs for the substitutable service sector when subsidies are netted out. Without subsidies, the size of the negative association in the substitutable service sector will be similar to that in the other two sectors. This implies the potential importance of subsidies in driving the level of market hours in the substitutable service sector.

\subsubsection{Two Margins of Substitution}

Using the time-use data from section 2.1.2, the middle panel in Table 2 reports the regression results of the share of market hours in total work hours (market plus home) against the effective tax and subsidy rates. The regressions for women show a negative correlation between the share of market hours and the effective tax, and a positive correlation with subsidies. The results are particularly strong for low-skilled women. This suggests that higher taxes induce women to substitute market hours with home hours, while social subsidies lead to the opposite substitution. For men, the above correlations are small, which indicates that the substitution margin between market and home is not as important for them.

The bottom panel in Table 2 reports similar regressions with the share of total work hours in total available time (market plus home plus leisure) being the dependent variable. The share of total work is negatively correlated with the effective tax for both genders and

\footnotetext{
${ }^{12}$ Chakraborty et al. (2015) report a close to zero cross-country correlation between female market hours and effective taxes. The main reasons for the different findings are the separation of women by skill level and the inclusion of subsidies. In addition, we follow the procedures outlined by Bick et al. (2016) and control for demographic composition.
} 
the correlations are stronger for men than for women. The correlations with subsidies are weak for both genders. This suggests that taxes are the dominant factor for the substitution margin between total work and leisure, and this margin is relatively more important for men.

\subsubsection{Gender Wage Ratio}

Figure 4 plots the cross-country difference in the gender wage ratio (female/male) by skill level. Almost all countries have higher gender wage ratios (i.e. lower gender wage gaps) for both skill levels, than the U.S. does. ${ }^{13}$

To summarize, this section documents that market hours in European countries are much lower for low-skilled women than in the United States, except in Nordic countries. Our conjecture is that the negative effect of taxes on market hours is larger for this group because the substitution between home and market services is stronger for them. This leads to a lower degree of marketization, and thus to lower market hours in the substitutable sector in high-tax countries. In Nordic countries, higher social subsidies on family care offset the effect of taxes. The evidence presented in this section is broadly consistent with this conjecture.

\section{The model}

This section presents an equilibrium model with three market sectors and a home production sector, in an environment with government taxes and subsidies. The three market sectors produce goods, non-substitutable services, and substitutable services, respectively. The production at home delivers a close substitute to the substitutable service produced in the market. Labor is supplied by a representative household to each sector and is indexed by gender and skill.

Government taxes labor income at rate $\tau$ and the consumption of market good $j$ at a net rate $t_{j}$, where $t_{j}$ is the gross consumption tax rate less the subsidy rate and $j$ takes values $1,2,3$, denoting the goods sector, the non-substitutable service sector, and the substitutable service sector, respectively. The subsidy is therefore modeled as a negative consumption tax and is applicable only to the consumption of the substitutable services. The net revenue from taxes less subsidies is rebated back to households as a form of lump-sum transfer $T$. The disutility from work is independent of sectors, and labor moves freely across sectors.

\footnotetext{
${ }^{13}$ The main exception occurs for the high-skilled in Sweden.
} 


\subsection{Firms}

Each of the three market sectors is competitive and consists of one representative firm. There are four types of labor inputs: high-skilled female, high-skilled male, low-skilled female and low-skilled male. While production in each sector utilizes all four types of inputs, the intensity of factor inputs differs. The production function in each sector takes a nested CES form capturing the finite elasticity across skills and across genders. The CES aggregator first combines labor inputs of men and women of the same skill level, and then combines the aggregated low-skilled and high-skilled labor inputs.

Let subscript $i$ index the skill level, where $i$ takes two values of $n$ and $e$, denoting low skill and high skill, respectively. Let $g$ index gender, where $g$ takes two values of $m$ and $f$, denoting male and female, respectively. The production function of sector $j$ is given by:

$$
Y_{j}=A_{j} L_{j}, \quad L_{j}=\left[\lambda_{j} L_{e j}^{\frac{\rho-1}{\rho}}+\left(1-\lambda_{j}\right) L_{n j}^{\frac{\rho-1}{\rho}}\right]^{\frac{\rho}{\rho-1}}, j=1,2,3,
$$

where $A_{j}$ is labor productivity and $L_{j}$ is an aggregator of the four labor inputs. $L_{e j}$ is the high-skill composite and $L_{n j}$ is the low-skill composite of female and male labor inputs. We allow $\lambda_{j} \in(0,1)$ to differ across sectors. This is to capture the difference in the sectoral intensity of skilled labor. The skill composites combine male and female labor inputs as follows:

$$
L_{i j}=\left[\xi_{i j} L_{i f j}^{\frac{\eta-1}{\eta}}+\left(1-\xi_{i j}\right) L_{i m j}^{\frac{\eta-1}{\eta}}\right]^{\frac{\eta}{\eta-1}}, i=n, e, j=1,2,3,
$$

where $L_{i f j}$ denotes the amount of female labor input and $L_{i m j}$ denotes the amount of male labor input with skill level $i$ in sector $j$. The parameter $\xi_{i j}$ affects the intensity of female labor input in producing the composite $L_{i j}$ and it varies by skill and sector. We say that

women of skill $i$ have a comparative advantage in sector $j$ whenever $\xi_{i j}>\max _{j^{\prime} \neq j}\left\{\xi_{i j^{\prime}}\right\}$. The parameter $\rho$ is the elasticity of substitution between low-skilled and high-skilled labor, and $\eta$ is the elasticity of substitution between female and male labor.

\subsection{The Representative Household}

The representative household consists of four types of labor, with a joint utility function:

$$
U\left(c_{1}, c_{2}, c_{3}, c_{h}, L_{l}\right)=\ln c+\varphi \ln L_{l},
$$

where the household derives utility from three types of goods and services: $c_{1}$ denotes market goods, $c_{2}$ denotes non-substitutable market services and $c_{s}$ denotes a composite of substi- 
tutable services, which aggregates substitutable market services $\left(c_{3}\right)$ and home services $\left(c_{h}\right)$ :

$$
c \equiv\left[\sum_{j=1,2, s} \omega_{j} c_{j}^{\frac{\epsilon-1}{\epsilon}}\right]^{\frac{\epsilon}{\epsilon-1}} ; \quad c_{s}=\left[\psi c_{3}^{\frac{\sigma-1}{\sigma}}+(1-\psi) c_{h}^{\frac{\sigma-1}{\sigma}}\right]^{\frac{\sigma}{\sigma-1}}
$$

where $\sum_{j=1,2, s} \omega_{j}=1$. The elasticity of substitution across different kind of goods and services is low with $0 \leq \varepsilon<1$ while the elasticity of substitution within substitutable services is high with $\sigma>1$.

Home services are produced with a technology similar to the one used in the substitutable market service sector (see (1)-(2)):

$$
c_{h}=A_{h} L_{h}, \quad L_{h}=\left[\lambda_{h} L_{e h}^{\frac{\rho-1}{\rho}}+\left(1-\lambda_{h}\right) L_{n h}^{\frac{\rho-1}{\rho}}\right]^{\frac{\rho}{\rho-1}},
$$

where

$$
L_{i h}=\left[\xi_{i h} L_{i f h}^{\frac{\eta-1}{\eta}}+\left(1-\xi_{i h}\right) L_{i m h}^{\frac{\eta-1}{\eta}}\right]^{\frac{\eta}{\eta-1}}, i=n, e,
$$

and $A_{h}$ is labor productivity for the home sector.

Leisure $L_{l}$ is a CES aggregator of male and female leisure time:

$$
L_{l}=L_{l}\left(L_{n l}, L_{e l}\right)=\left[\lambda_{l} L_{e l}^{\frac{\rho_{l}-1}{\rho_{l}}}+\left(1-\lambda_{l}\right) L_{n l}^{\frac{\rho_{l}-1}{\rho_{l}}}\right]^{\frac{\rho_{l}}{\rho_{l}-1}}
$$

where

$$
L_{i l}=\left[\xi_{i l} L_{i f l}^{\frac{\eta_{l}-1}{\eta_{l}}}+\left(1-\xi_{i l}\right) L_{i m l}^{\frac{\eta_{l}-1}{\eta_{l}}}\right]^{\frac{\eta_{l}}{\eta_{l}-1}}, i=n, e,
$$

and the elasticity of substitution $\eta_{l}<1$, indicating male and female's leisure time are poor substitutes.

The household is endowed with $L_{i g}(g=m, f$ and $i=n, e)$ units of labor of skill $i$ and gender $g$. Taking as given government policy parameters $\left(t_{1}, t_{2}, t_{3}, T\right)$, wages $\left\{w_{i f}, w_{i m}\right\}_{i=n, e}$, and prices $\left(p_{1}, p_{2}, p_{3}\right)$, a representative household chooses market consumption $\left(c_{1}, c_{2}, c_{3}\right)$, home production time $\left\{L_{i m h}, L_{i f h}\right\}_{i=n, e}$ and leisure time $\left\{L_{i m l} L_{i f l}\right\}_{i=n, e}$ to maximize the utility function (3) subject to (4)-(8) and the household budget constraint:

$$
\sum_{j=1,2,3}\left(1+t_{j}\right) p_{j} c_{j}=T+(1-\tau) \sum_{i, g} w_{i g}\left(L_{i g}-L_{i g h}-L_{i g l}\right)
$$




\subsection{Competitive Equilibrium}

A competitive equilibrium is defined by wages $\left\{w_{i f}, w_{i m}\right\}_{i=n, e}$, prices and consumption $\left\{p_{j}, c_{j}\right\}_{j=1,2,3}$ and time allocation $\left\{L_{i f j}, L_{i m j}\right\}_{\forall i, j}$ such that:

1. Given wages and prices, the firms maximize profits subject to production functions (1)-(2); and the representative household maximizes utility (3) subject to (4)-(9).

2. Given the optimal decisions of the firms and the household, wages and prices clear the goods market and the labor market:

$$
\begin{aligned}
c_{j} & =Y_{j}, \quad j=1,2,3, \\
\sum_{j=1,2,3} L_{i g j} & =L_{i g}-L_{i g h}-L_{i g l}, \quad i=n, e ; \quad g=f, m .
\end{aligned}
$$

3. Government budget constraint is satisfied:

$$
T=\tau \sum_{i, g} w_{i g}\left(L_{i g}-L_{i g h}-L_{i g l}\right)+\sum_{j=1,2,3} t_{j} p_{j} c_{j} .
$$

The derivation of the competitive equilibrium is provided in the Online Appendix.

\subsection{Hours by Sector and By Gender}

This section provides intuition on how taxes and subsidies affect the allocation of hours across sectors and population groups. We assume the consumption tax rate on goods and non-substitutable services is the same, i.e., $t_{1}=t_{2}$, while the effective consumption tax rate on substitutable services could be smaller, and the difference between $t_{3}$ and $t_{1}$ (or $t_{2}$ ) captures the subsidy from the government.

We first discuss the effect of taxes and subsidies on the time allocation of low-skilled women. By equalizing the marginal rate of substitution between substitutable market services and home hours to their relative prices, the relative time allocation for low-skilled women across home and the substitutable sector is given by:

$$
\frac{L_{n f 3}}{L_{n f h}}=\hat{A}_{3 h}^{\sigma-1}\left(\frac{1-\tau}{1+t_{3}}\right)^{\sigma} R_{3 h}(X), \quad \hat{A}_{3 h} \equiv\left(\frac{A_{3}}{A_{h}}\right)\left(\frac{\psi}{1-\psi}\right)^{\frac{\sigma}{\sigma-1}}
$$

where $\hat{A}_{3 h}$ is the effective relative productivity and $R_{3 h}(X)$ is a function that only depends on the vector of relative wages, $X$, and parameters in the production functions of sectors 3 and $h$. 
Ignoring the general equilibrium effect through relative wages, equation (13) implies that higher subsidies (lower $t_{3}$ ) shift low-skilled female hours from the home sector to the substitutable service sector. Intuitively, a fall in the price of substitutable market services (due to higher subsides) induces households to substitute other consumption and leisure with these services. As home services are a close substitute to substitutable market services, the household mainly substitutes away from home services. This implies that the substitution between market and home work is important in propagating the effect of subsidies, while the margin between work and leisure is not as important.

In contrast, higher income taxes reduce the after-tax wages and higher consumption taxes raise the price of all market consumption relative to home services and leisure, and thus both lead to a shift of low-skilled female hours from market production to home production and leisure. The effect through the market and home margin is similar to that of subsidies and reduces hours in the substitutable sector more than in the other market sectors. The effect through the work and leisure margin leads to a reduction in total work hours and a rise in leisure.

To understand the effect of taxes and subsidies on other population groups, we first derive the relative time allocation across gender-skill groups. Given free labor mobility, profit maximization of the firms and utility maximization of the household imply that marginal rates of technical substitution across genders are equal to the gender wage ratio, which gives:

$$
\frac{L_{i m j}}{L_{i f j}}=\alpha_{i j}^{-\eta} x_{i}^{\eta} ; \quad \alpha_{i j} \equiv \frac{\xi_{i j}}{1-\xi_{i j}}, \quad x_{i} \equiv \frac{w_{i f}}{w_{i m}}, \quad j=1,2,3, h ; \quad i=n, e,
$$

where $x_{i}$ is the gender wage ratio for skill group $i$. Thus, the effects of taxes and subsidies on gender-hour ratios only operate through their effects on the equilibrium gender wage ratios.

In a similar vein, given free labor mobility, profit and utility maximization imply that marginal rates of technical substitution across skills are equal to the skill premium, which gives:

$$
\frac{L_{e f j}}{L_{n f j}}=\left(\frac{\lambda_{j}}{1-\lambda_{j}}\right)^{\rho}\left(\frac{\xi_{e j}}{\xi_{n j}}\right)^{\frac{\eta(\rho-1)}{\eta-1}}\left(\frac{1+\alpha_{n j}^{-\eta} x_{n}^{\eta-1}}{1+\alpha_{e j}^{-\eta} x_{e}^{\eta-1}}\right)^{\frac{\eta-\rho}{\eta-1}} \pi_{f}^{-\rho}, \quad \pi_{f} \equiv \frac{w_{e f}}{w_{n f}}, \quad j=1,2,3, h
$$

where $\pi_{f}$ is the female skill premium. Equation (15) implies that the effects of taxes and subsidies on the hour ratios across skills only operate through their effects on equilibrium relative wages.

Substituting equations (14) and (15) into equation (13) illustrates that taxes and subsidies affect the market and home margin of other population groups in a way similar to 
the one of low-skill women. The magnitude of these effects however, will crucially depend on the comparative advantage parameters $\xi_{i j}$ and the skill intensity parameters $\lambda_{j}$. In particular, if women have a comparative advantage in producing substitutable market services $\xi_{i 3}>\left\{\xi_{i 1}, \xi_{i 2}\right\}$, their responses to taxes and subsidies will be larger than those of men. Furthermore, high-skill groups will respond less to changes in policy because their comparative advantages are usually not in substitutable services (whose production is less skill-intensive). Hence, the market and home margin is more important for women, especially for low-skilled women.

In summary, taxes affect hours through both the market and home, and the work and leisure margins. Subsidies in contrast, affect hours mainly through the market and home margin. The market and home margin is more important for low-skilled women because of their comparative advantage in producing substitutable market services.

\section{Quantitative Results}

\subsection{Calibration}

The model is calibrated to match time allocation and wage ratios in the U.S. economy around the year 2000 (the average of 2000-2004). Predictions for other countries are obtained by simulating the model with the country-specific taxes and subsidies. The full calibration procedures are documented in the Online Appendix. The basic principle is as follows. Given the tax parameters $\left\{\tau, t_{1}, t_{2}, t_{3}\right\}$, the parameters needed to determine time allocation and wage ratios include the elasticity parameters $\left\{\sigma, \varepsilon, \rho, \eta, \rho_{l}, \eta_{l}\right\}$; the relative time endowment $\left\{\frac{L_{e f}}{L_{e m}}, \frac{L_{n f}}{L_{n m}}, \frac{L_{e f}}{L_{n f}}\right\}$; the gender-specific parameters $\left\{\xi_{i j}\right\}_{\forall i, j}$; the skill-specific parameters $\left\{\lambda_{j}\right\}_{\forall j}$; the preference parameter on leisure $\varphi$; and the relative productivity $\left\{\hat{A}_{3 h}, \hat{A}_{23}, \hat{A}_{12}\right\}$, which are functions of the sectoral labor productivities, $A_{j}$, and preference parameters $\left\{\psi, \omega_{j}\right\} .{ }^{14}$

The six elasticity parameters $\left\{\sigma, \varepsilon, \rho, \eta, \rho_{l}, \eta_{l}\right\}$ for preferences and production functions are directly set to values derived elsewhere in the literature. The elasticity of substitution between substitutable services and home services, $\sigma$, is set to 1.9 which is the mid-point of the estimates in the literature ranging from 1.5 to $2.3 .{ }^{15}$ The elasticity of substitution across

\footnotetext{
${ }^{14} \hat{A}_{12} \equiv \frac{A_{1}}{A_{2}}\left(\frac{\omega_{2}}{\omega_{1}}\right)^{\frac{\varepsilon}{1-\varepsilon}}, \hat{A}_{23} \equiv \frac{A_{2}}{A_{3}}\left(\frac{\omega_{s}}{\omega_{2}}\right)^{\frac{\varepsilon}{1-\varepsilon}} \psi^{\frac{\sigma}{1-\sigma}}$, and $\hat{A}_{3 h} \equiv\left(\frac{A_{3}}{A_{h}}\right)\left(\frac{\psi}{1-\psi}\right)^{\frac{\sigma}{\sigma-1}}$. Separate information on $\left\{\psi, \omega_{j}\right\}$ is not needed for the prediction of relative time allocations.

${ }^{15}$ See the survey by Aguiar, Hurst and Karabarbounis (2012) and Rogerson and Wallenius (2016). For individual papers, see for example, Rupert, Rogerson and Wright (1995), Chang and Schorfheide (2003), McGrattan, Rogerson and Wright (1997), Aguiar and Hurst (2007a), Gelber and Mitchell (2012), and Fang and Zhu (2017).
} 
goods and services, $\epsilon$, is set to 0 given that Herrendorf, Rogerson and Valentinyi (2013) and Moro, Moslehi and Tanaka (2017) both estimated a value not significantly different from zero. The elasticity between low-skilled and high-skilled labor $\rho$ is set to 1.42 as in Katz and Murphy (1992). For the elasticity between female and male labor, Weinberg (2000) finds an estimate of 2.4 and Acemoglu, Autor and Lyle (2004) find estimates between 2.5 and 4. The benchmark value of $\eta$ is set at 3 . There are no readily available estimates for $\rho_{l}$ and $\eta_{l}$. We set the benchmark value of $\rho_{l}=\rho=1.42$ for the elasticity across high-skilled and low-skilled leisure time. As for the elasticity of substitution across male and female time in leisure, empirical papers have argued for complementarity of male and female leisure time (see Goux, Maurin and Petrongolo (2014), and references therein), suggesting $\eta_{l}<1$. Using time-use data for the U.S., Ngai and Petrongolo (2017) find that $\eta_{l}=0.19$ matches the response of the gender hour ratio to changes in gender wage ratio from 1970 to 2006. This low value of $\eta_{l}$ is due to the rather stable gender ratio in total work hours. Thus $\eta_{l}=0.2$ is used as the benchmark.

The remaining twenty-two parameters are calibrated to match relative wages and time allocation for each of the four types of labor inputs in the five sectors (three market sectors, a home sector, and leisure). There are a total of twenty-two independent data targets used to calibrate the twenty-two parameters. The Online Appendix explains how each of these parameters are uniquely pinned down by the data targets. In a nutshell, the data targets deliver the fraction of time allocated to each sector $\left\{\frac{L_{i g j}}{L_{i g}}\right\}$. Given the time allocation, the share of market hours in the substitutable service sector as a fraction of total high-skilled hours, low-skilled hours and aggregate hours are used to derive the relative endowment $\left\{\frac{L_{e f}}{L_{e m}}, \frac{L_{n f}}{L_{n m}}, \frac{L_{e f}}{L_{n f}}\right\}$. The equilibrium condition for gender wage ratios (14) is used to solve for $\left\{\xi_{i j}\right\}$. The equilibrium condition for skill premium (15) is used to solve for $\left\{\lambda_{j}\right\}$. Finally, the

final four parameters $\left\{\varphi, \hat{A}_{12}, \hat{A}_{23}, \hat{A}_{3 h}\right\}$ are calibrated to match the relative time allocation across the five sectors for low-skilled women. The baseline parameter values are summarized in Table 3. The data targets are reported in the Online Appendix following the discussion of the calibration procedures.

\subsection{The Role of Taxes}

This subsection reports the quantitative results using only the country-specific income and consumption taxes, i.e. setting $t_{3}=t_{1}=t_{2}$. The next subsection discusses the effect of social subsidies.

We first compare the prediction of the model on market hours for the four demographic groups with the data. Table 4 shows that the model predicts lower market hours for each 
gender-skill group in all European countries and Canada. More importantly, for European countries the model predicts larger percentage differences in female market hours, especially for the low-skilled, from the U.S., which is consistent with the data facts presented in Section 2.2. The model's predictions on sectoral market hours, as reported in Table 5, are also broadly consistent with the data. Predicted market hours in the two service sectors are uniformly lower than in the United States. Predicted market hours in the goods sector are also uniformly lower, while in the data they are higher in a few European countries. However, because market hours in the goods sector are only about $25 \%-30 \%$ of the total market hours in the sample countries, the opposite prediction does not lead to significant differences in the level of total market hours.

As shown in the first two columns of Table 5, on average the model closely predicts the differences in aggregate market hours between Central European countries, Canada, and the U.S., and it also predicts $89 \%$ of the difference between Southern European countries and the U.S.; while it over-predicts the difference between Nordic Countries and the United States. Table 4 reveals that the model particularly over-predicts the difference in female market hours between Nordic Countries and the United States. In the next subsection we introduce social subsidies which as argued by several authors, are essential in understanding hours of work in Nordic countries.

We next turn to the model prediction of the cross-country variation of market hours. Figure 5 plots the model predicted market hours by gender, skill and sector against the data. If the model accounts perfectly for the data, all the markers would align along the 45-degree line. To statistically evaluate the performance of the model, the bottom panels of Tables 4 and 5 report several goodness-of-fit statistics. As is well known, the correlation coefficient measures the linear association between the model predictions and the data. However, it is not a great measure to detect deviations from the 45-degree line. The concordance correlation is a statistic that measures instead the mean square deviations from the 45-degree line and it always lies between -1 and 1 (Lin 1989). Hence, it is the preferred measure to evaluate the model's fit with the data. Nonetheless, we also report the correlation coefficient. ${ }^{16}$

The concordance correlation is 0.35 for aggregate market hours and ranges from 0.03 for low-skilled women to 0.48 for low-skilled men. ${ }^{17}$ The model predictions on sectoral market hours are also consistent with the data but slightly weaker. The concordance correlation is 0.17 for the goods sector, 0.15 for the substitutable service sector, and 0.05 for the nonsubstitutable service sector.

\footnotetext{
${ }^{16}$ We define and compare these statistics in the Online Appendix.

${ }^{17}$ All the reported goodness-of-fit measures exclude the United States, as the model was calibrated to the U.S. values.
} 


\subsection{The Role of Social Subsidies}

Tables 6 and 7 report the results when we allow social subsidies on the consumption of substitutable services. The inclusion of subsidies greatly improves the prediction of market hours in Nordic countries, especially for women, and has relatively small effects on market hours in Central and Southern European countries. This is because the subsidy rate, as reported in Table A4, is much larger in Nordic countries.

The inclusion of subsidies also improves most of the goodness-of-fit measures. The largest improvements occur for the predictions for low-skilled women and for the substitutable service sector. In the case of low-skilled women, the concordance correlation is more than tripled and for the substitutable sector this coefficient increases by more than $50 \%$. The prediction on total market hours also improves with subsidies, with the concordance correlation increasing by $20 \%$. The improvement is also evident in Figure 5, as the model predictions with subsidy are closer to the 45-degree line.

The model mechanism has two important implications. First, higher social subsidies reduce the relative price of substitutable market services and lead to the substitution from home services to their market equivalents. This implication is consistent with the evidence present in Table A5, which shows that subsidies have a strong positive correlation with various measures of formal care used by children, old people, and people with disabilities, suggesting a shift of care usage from home to market when subsidies rise. ${ }^{18}$

Second, as a consequence of the above, higher social subsidies lead to the shift of lowskilled female hours from home to the substitutable market service sector. This is consistent with the evidence presented in Table A6, which breaks down the employment of each population group by sector. The table shows that more than $60 \%$ of low-skilled women are either working in the substitutable service sector or not employed. This suggests that a large fraction of low-skilled women are involved in either providing home services or their market substitutes. ${ }^{19}$ However, there are important cross-country differences on whether such services are produced at home or in the market. In particular, in countries with high taxes and low subsidies (Central and Southern Europe) only 50-60\% of low-skilled women are employed. However, in countries with low taxes (U.S.) or with high-taxes and high-subsides (Nordic countries) $70 \%$ of low-skilled women are employed and they mainly work to provide substitutes to home services. ${ }^{20}$

\footnotetext{
${ }^{18} \mathrm{By}$ formal care we mean the care provided by institutions (e.g. day-care, schools, retirement homes, rehabilitation centers, but excluding hospitals), as well as paid-care at home.

${ }^{19}$ Using U.S. data, Mazzolari and Ragusa (2013) show that non-college workers participate more intensely in market services that are substitute to home services. They also show that marketization of home services can account for about one-third of the employment growth of low-wage workers between 1980 and 2005 .

${ }^{20}$ As expected, this table also shows that skilled individuals (of both genders) have a strong participation
} 
Our measure of social subsidies may underestimate the government support to households, as it is computed from the in-kind government expenditures in the SOCX database. Nordic countries also have many other family-friendly policies, such as larger tax credits and exemptions for domestic service. ${ }^{21}$ These policies, if they could be quantified, would lead to higher female market hours than the ones predicted by our model, and so improve further the model's prediction for Nordic countries.

\subsection{Two Margins of Substitution}

In our model, taxes and subsidies work through the two substitution margins: market work versus home work (i.e. marketization), and total work versus leisure. The model predictions on these two margins are reported in Tables 8 and 9 . The tables only contain nine countries where time use surveys are available.

Table 8 shows that under higher taxes women shift their market hours to home production, and with higher subsidies they do the opposite. This is consistent with the data facts presented in Table 2. In Nordic countries, the model again over-predicts the shift in female market hours to home production, and social subsidies reduce this over-prediction. The effect of subsidies on female market hours is also evident in Figure 6: When social subsidies are included, the model predictions on the share of market hours for females move towards the 45-degree line and the concordance correlation increases from close to zero to 0.28 for low-skilled women and to 0.25 for high-skilled women. The improvement mainly comes from the better prediction for women in Nordic countries. The concordance correlation for the share of market hours of males is small regardless of social subsidies, which is not surprising, because as shown in Table 2, taxes and subsidies are not correlated with the share of male market hours.

Figure 7 and Table 9 report time allocation along the total work versus leisure margin. As the table shows, in the data the share of total work is lower in European countries than in the U.S. for both men and women. The model with higher taxes can deliver this result because the substitution along the work-leisure margin is important for both genders, which is also consistent with the data facts presented in Table 2. The concordance correlation ranges from 0.17 to 0.42 , implying that the model also does a good job in predicting the cross-country variation in the share of total work. Because subsidies mainly affect the time allocation between market hours and home hours, they almost have no effect on the share of total work.

in non-substitutable services, while low-skilled men are mainly employed in the production of goods.

${ }^{21}$ Carbonnier and Morel, eds (2015) discuss the potential consequences on the labor market of alternative policies, including tax credits and exemptions on the purchases of care services in the private market. 


\subsection{Gender Wage Ratio}

Table 10 reports the gender wage ratio (women/men). When compared with the United States, the model predicts higher gender wage ratios for both skill groups in all European countries and Canada. The intuition is that higher taxes lead to larger decreases in market hours for women and thus a rise in female wages relative to male. Together with subsidies, the model on average can account for $17 \%$ of the difference in the low-skilled gender wage ratio and $14 \%$ of the difference in the high-skilled gender wage ratio between European countries and the United States.

Table 10 reveals that the concordance correlations are low, with or without subsidies. Figure 8 confirms that taxes and subsidies alone cannot account for the large variation in the gender wage ratio across countries. We view these results as an indication that other complementary factors such as labor market institutions, culture and discrimination are important for understanding the cross-country differences in this ratio (see Blau and Kahn (2000) and Blau and Kahn (2003)). Another channel documented by Olivetti and Petrongolo (2008) is the self-selection of high ability women into the labor market in Southern Europe, leading to higher gender wage ratios in these countries.

\subsection{Robustness}

This subsection discusses some robustness checks of the benchmark results. For each case below, we recalibrate the model to the same set of targets as before.

We first explore the effects of alternative values for the elasticity of substitution between substitutable market services and home services $(\sigma)$. Alternative values for this elasticity do not change the mechanism of the model and thus do not change the qualitative predictions across gender-skill groups. The literature finds estimates for $\sigma$ between 1.5 and 2.3. Setting $\sigma$ to the upper (lower) bound leads to only one more (less) percentage point difference in the aggregate market hours for the European average relative to the United States. The concordance correlations hardly change.

Also, setting alternative values for $\eta=\{2.5,4\}, \eta_{l}=\{0,1\}$, and $\rho_{l}=\{0,2\}$ has no effect

on the concordance correlation, and at most leads to one-tenth of a percentage point change from the benchmark simulation for the difference in the aggregate market hours between the European average and the United States. Thus, our results are robust to variations in the key elasticity parameters within the entire range of empirical estimates in the recent literature. 


\section{Conclusion}

Using micro data from 17 OECD countries, this paper documents that low-skilled women is the population group contributing the most to the cross-country differences in aggregate market hours between Europe and the U.S., except in Nordic countries. Using a multisector model that allows for both gender and skill differences in market work, home work and leisure, we show that taxes and social subsidies on family care can account for the different patterns of female market hours between Nordic and other European countries. Both substitution margins across work and leisure and across market and home work are important. Higher taxes reduce market hours through both margins, while higher social subsidies increase market hours mainly through the market and home margin. This reversal helps reconcile the patterns observed in Nordic countries, where both taxes and subsidies are high, and women have relatively high market hours of work.

Our study has implications that go beyond the European context and that concern more generally the types of policies that can be used to promote the participation of women in the market. For instance, the International Labour Organization (2016) documents that the gender gap in employment is much larger in many developing countries, and as in the case of Europe, women do most of the housework. That report also suggests that higher government spending on family policies, such as social care services, policies on family leave and familyfriendly work schedules, are associated with higher female employment-to-population ratios. This is consistent with our finding that the key to increase female market hours is to establish

policies that reduce the cost of marketizing home production. Among these policies, we studied the in-kind social subsidies such as family care, and showed that this seemingly gender-neutral policy is effectively gender-biased, given women's comparative advantage in family-oriented activities. 


\section{References}

Acemoglu, Daron, David Autor, and David Lyle, "Women, War, and Wages: The Effect of Female Labor Supply on the Wage Structure at Midcentury," Journal of Political Economy, 2004, 112 (3), 497-551.

Adema, Willem, Pauline Fron, and Maxime Ladaique, "Is the European Welfare State Really More Expensive?: Indicators on Social Spending, 1980-2012; and a Manual to the OECD Social Expenditure Database (SOCX)," OECD Social, Employment and Migration Working Papers 124, 2011. OECD Publishing, http://dx.doi.org/10.1787/5kg2d2d4pbf0-en.

Aguiar, Mark and Erik Hurst, "Life-Cycle Prices and Production," American Economic Review, December 2007, 97 (5), 1533-1559.

and __ , "Measuring Trends in Leisure: The Allocation of Time Over Five Decades," Quarterly Journal of Economics, 2007, 122 (3), 969-1006.

, and Loukas Karabarbounis, "Recent Developments in the Economics of Time Use," Annual Review of Economics, 2012, 4, 373-397.

Barczyk, Daniel and Matthias Kredler, "Long-Term Care Across Europe and the U.S.: The Role of Informal and Formal Care," 2018. unpublished manuscript.

Bick, Alexander and Nicola Fuchs-Schündeln, "Taxation and Labor Supply of Married Couples across Countries: A Macroeconomic Analysis," The Review of Economic Studies, forthcoming.

— _ Bettina Brüggemann, and Nicola Fuchs-Schündeln, "Hours Worked in Europe and the US: New Data, New Answers," IZA Discussion Paper Series 10179, 2016.

Blau, Francine D. and Lawrence M. Kahn, "Gender Differences in Pay," Journal of Economic Perspectives, 2000, 14 (4), 75-99.

and __ , "Understanding International Differences in the Gender Pay Gap," Journal of Labor Economics, 2003, 21 (1), 106-144.

Burda, Michael, Daniel S. Hamermesh, and Philippe Weil, "Total work and gender: facts and possible explanations," Journal of Population Economics, 2013, 26 (1), 239 261. 
Carbonnier, Clément and Nathalie Morel, eds, The Political Economy of Household Services in Europe, Palgrave Macmillan, 2015.

Cattan, Sarah, "Can universal preschool increase the labor supply of mothers?," IZA World of Labor, 2016, (312), 1-10.

Chakraborty, Indraneel, Hans A. Holter, and Serhiy Stepanchuk, "Marriage stability, taxation and aggregate labor supply in the U.S. vs. Europe," Journal of Monetary Economics, 2015, 72, 1-20.

Chang, Yongsung and Frank Schorfheide, "Labor-supply shifts and economic fluctuations," Journal of Monetary Economics, 2003, 50 (8), 1751-1768.

Duernecker, Georg and Berthold Herrendorf, "On the allocation of time - A quantitative analysis of the roles of taxes and productivities," European Economic Review, 2018, 102, 169-187.

Eurostat, "European Community Household Panel [dataset]," 2003. European Comission.

_ _ "European Union Statistics on Income and Living Conditions, 2003-2005 [dataset]," 2014. European Comission.

__ , "EU Labour Force Survey, Version November 2015 [dataset]," 2015. European Comission.

Fang, Lei and Cara McDaniel, "Home Hours in the United States and Europe," B. E. Journal of Macroeconomics, Jan. 2017, 17 (1), 1-27.

and Guozhong Zhu, "Time Allocation and Home Production Technology," Journal of Economic Dynamics and Control, May 2017, 78, 88-101.

Flood, Sarah, Miriam King, Steven Ruggles, and J. Robert Warren, "Integrated Public Use Microdata Series, Current Population Survey: Version 4.0. [dataset]," http://doi.org/10.18128/D030.V4.0, 2015. Minneapolis: University of Minnesota.

Freeman, Richard B. and Ronald Schettkat, "Marketization of Household Production and the EU-US Gap in Work," Economic Policy, 2005, 20 (41), 7-39.

Galor, Oded and David Weil, "The Gender Gap, Fertility, and Growth," American Economic Review, 1996, 86 (3), 374-387.

Gelber, Alexander M. and Joshua W. Mitchell, "Taxes and Time Allocation: Evidence from Single Women and Men," Review of Economic Studies, 2012, 79 (3), 863-897. 
Goux, Dominique, Eric Maurin, and Barbara Petrongolo, "Worktime Regulations and Spousal Labour Supply," American Economic Review, 2014, 104 (1), 252-276.

Guner, Nezih, Remzi Kaygusuz, and Gustavo Ventura, "Child-Related Transfers, Household Labor Supply and Welfare," HCEO Working Paper Series, 2017-001, 2017.

Hannusch, Anne, "The Impact of Child-Related Transfers and Informal Childcare on the Labor Supply of Women with Children," 2018. unpublished manuscript.

Herrendorf, Berthold, Richard Rogerson, and Ákos Valentinyi, "Two Perspectives on Preferences and Structural Transformation," American Economic Review, 2013, 103 (7), 2752-2789.

Insee, "Enquête Emploi, 2000-2004. [dataset]," 2014. L'Institut national de la statistique et des études économiques.

International Labour Organization, Women at Work. Trends 2016, International Labour Office - Geneva: ILO, 2016.

Katz, Lawrence F. and Kevin M. Murphy, "Changes in Relative Wages, 1963-1987: Supply and Demand Factors," Quarterly Journal of Economics, 1992, 107 (1), 35-78.

Lin, Lawrence I-Kuei, "A Concordance Correlation Coefficient to Evaluate Reproducibility," Biometrics, 1989, 45 (1), 255-268.

Mazzolari, Francesca and Giuseppe Ragusa, "Spillovers from High-Skill Consumption to Low-Skill Labor Markets," Review of Economics and Statistics, 2013, 95 (1), 74-86.

McDaniel, Cara, "Average tax rates on consumption, investment, labor and capital in the OECD 1950-2003," 2007. unpublished manuscript.

—_ , "Forces Shaping Hours Worked in the OECD, 1960-2004," American Economic Journal: Macroeconomics, October 2011, 3 (4), 27-52.

McGrattan, Ellen R., Richard Rogerson, and Randall Wright, "An Equilibrium Model of the Business Cycle with Household Production and Fiscal Policy," International Economic Review, 1997, 38 (2), 267-290.

Minnesota Population Center, "Integrated Public Use Microdata Series, International: Version 6.5 [dataset]," http://doi.org/10.18128/D020.V6.5, 2017. Minneapolis: University of Minnesota. 
Moro, Alessio, Solmaz Moslehi, and Satoshi Tanaka, "Does Home Production Drive Structural Tranformation?," American Economic Journal: Macroeconomics, 2017, 9 (3), 116-146.

Ngai, L. Rachel and Barbara Petrongolo, "Gender Gaps and the Rise of the Service Economy," American Economic Journal: Macroeconomics, 2017, 9 (4), 1-44.

and Christopher A. Pissarides, "Taxes, Social Subsidies, and the Allocation of Work Time," American Economic Journal: Macroeconomics, October 2011, 3 (4), 126.

Ohanian, Lee, Andrea Raffo, and Richard Rogerson, "Long-term changes in labor supply and taxes: Evidence from OECD Countries, 1956-2004," Journal of Monetary Economics, 2008, 55 (8), 1353-1362.

Olivetti, Claudia and Barbara Petrongolo, "Unequal Pay or Unequal Employment? A Cross-Country Analysis of Gender Gaps," Journal of Labor Economics, 2008, 26 (4), $621-654$.

and __ , "Gender gaps across countries and skills: Demand, supply and the industry structure," Review of Economic Dynamics, 2014, 17 (4), 842-859.

Olovsson, Conny, "Why do Europeans work so little?," International Economic Review, 2009, 50 (1), 39-61.

ONS, "Quarterly Labour Force Survey, 2000-2004. [data collection]," Retrieved from https://discover.ukdataservice.ac.uk/series/?sn=2000026, 2015. Office for National Statistics. Social Survey Division and Northern Ireland Statistics and Research Agency. Central Survey Unit.

Prescott, Edward C, "Why Do Americans Work So Much More Than Europeans?," Federal Reserve Bank of Minneapolis Quarterly Review, 2004, 28 (July), 2-13.

Ragan, Kelly S., "Taxes and Time Use: Fiscal Policy in a Household Production Model," American Economic Journal: Macroeconomics, 2013, 5 (1), 168-192.

Rendall, Michelle, "Brain versus Brawn: The Realization of Women's Comparative Advantage," 2017. unpublished manuscript.

_ - "Female market work, tax regimes, and the rise of the service sector," Review of Economic Dynamics, forthcoming. 
Rogerson, Richard, "Structural Transformation and the Deterioration of European Labor Market Outcomes," Journal of Political Economy, April 2008, 116 (2), 235-259.

and Johanna Wallenius, "Retirement, home production and labor supply elasticities," Journal of Monetary Economics, 2016, 78, 23-34.

Rupert, Peter, Richard Rogerson, and Randall Wright, "Estimating Substitution Elasticities in Household Production Models," Economic Theory, June 1995, 6 (1), $179-93$.

Socio-Economic Panel (SOEP), "Data for years 2000-2004, version 30, SOEP," 2015. doi:10.5684/soep.v30.

Timmer, Marcel P., Erik Dietzenbacher, Bart Los, Robert Stehrer, and Gaaitzen J. de Vries, "An Illustrated User Guide to the World Input-Output Database: the Case of Global Automotive Production," Review of International Economics, 2015, 23 (3), 575-605.

, Mary O'Mahony, and Bart van Ark, "EU KLEMS Growth and Productivity Accounts: An Overview," downloadable at www.euklems.net, 2007. University of Groningen \& University of Birmingham.

Urban Institute, "National Survey of America's Families (NSAF), 2002 [dataset]," ICPSR 4582, 2002. Inter-university Consortium for Political and Social Research [distributor].

Wagner, Gert G., Joachim R. Frick, and Jürgen Schupp, "The German SocioEconomic Panel Study (SOEP) - Scope, Evolution and Enhancements," Schmollers Jahrbuch, 2007, 127 (1), 139-169.

Weinberg, Bruce A., "Computer Use and the Demand for Female Workers," Industrial and Labor Relations Review, 2000, 53 (2), 290-308. 


\section{Figures and Tables}

Figure 1: Hours Worked in the Market by Population Group Relative to the U.S.

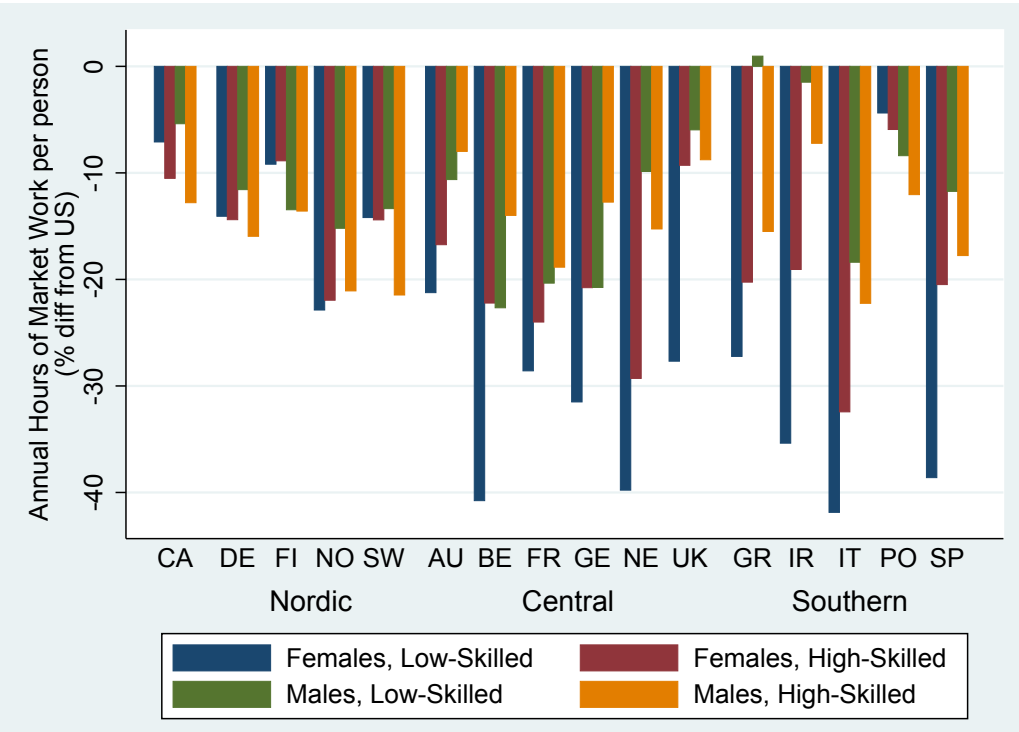

Hours are adjusted for demographic differences across countries. Low-skilled individuals are those without a college degree. Data cover years 2000-2004.

Figure 2: Hours Worked by Sector Relative to the U.S.

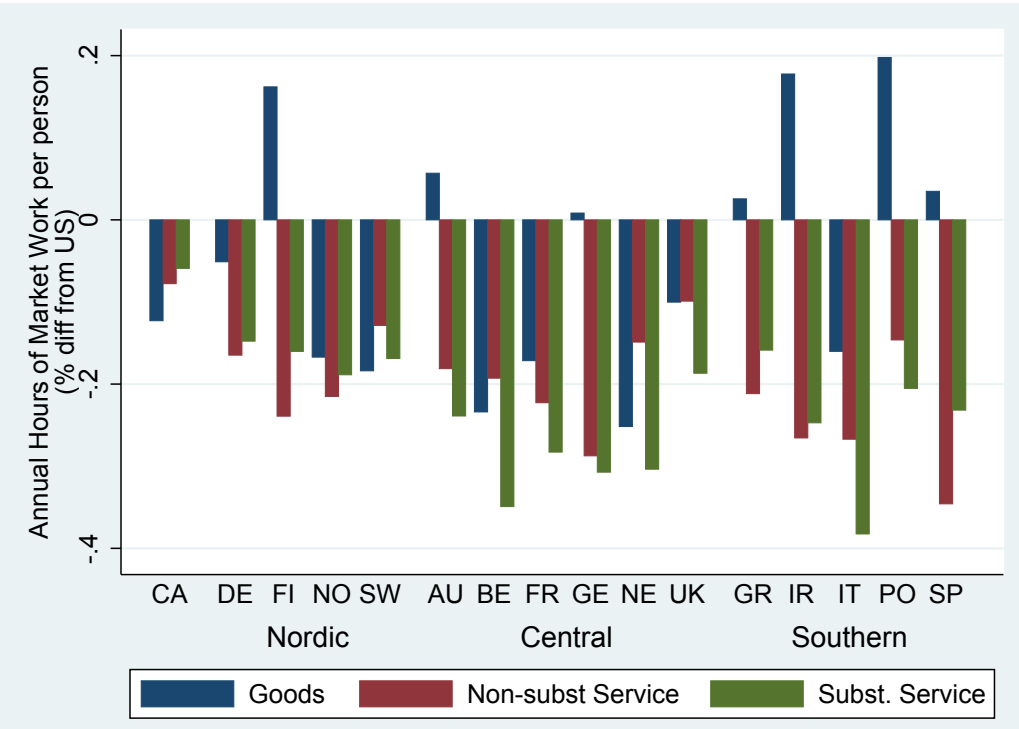

Hours are adjusted for demographic differences across countries. Data cover years 2000-2004. 
Figure 3: Hours Worked by Sector and Effective Taxes

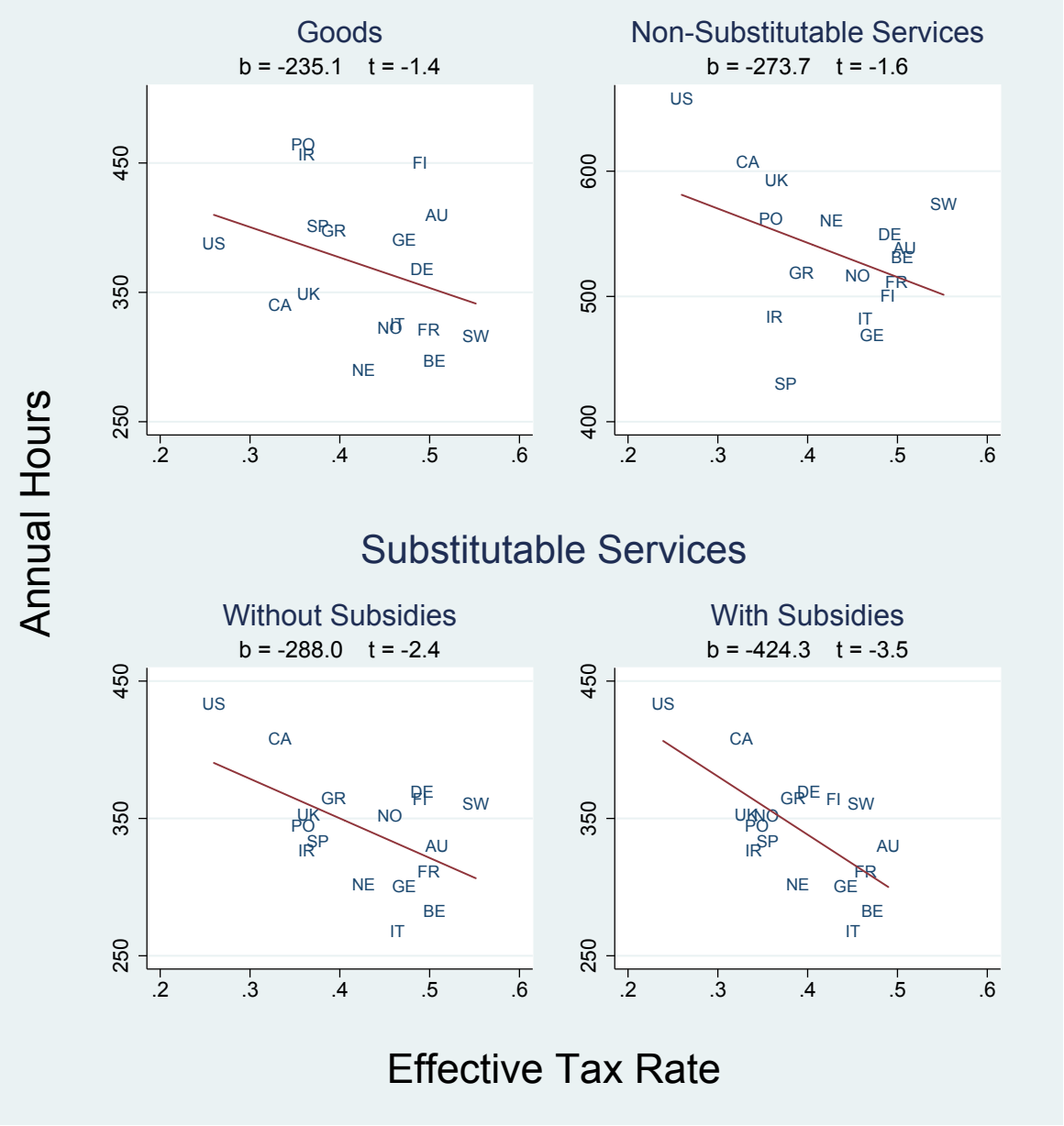


Figure 4: Gender Wage Ratio Relative to the US

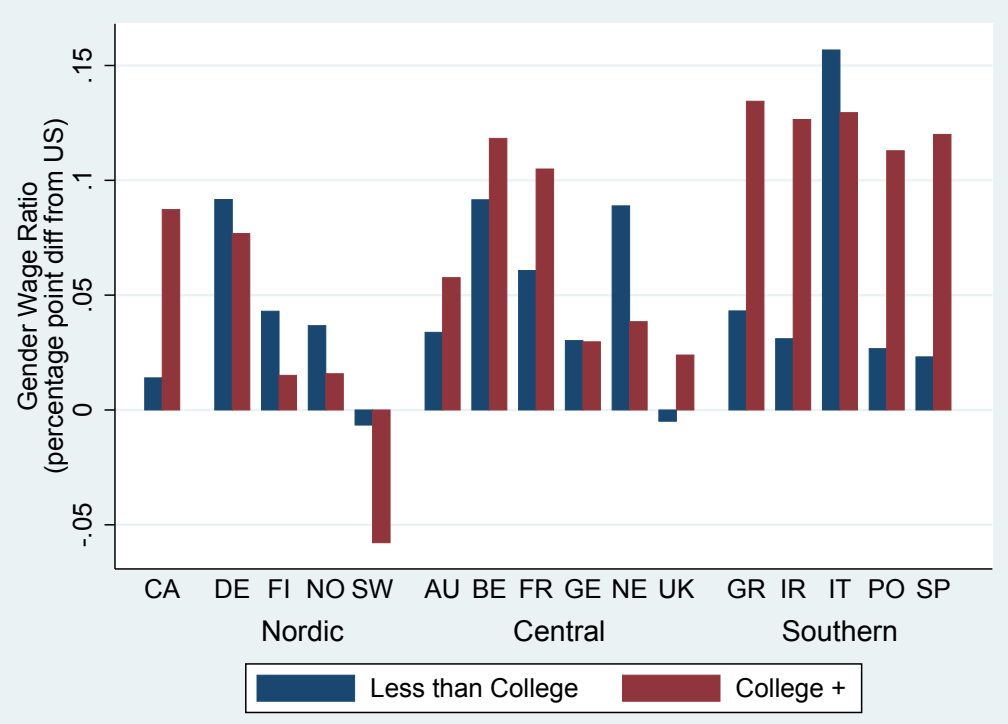

Wage ratios are adjusted for age and marital status. Data cover years 2000-2004. 
Figure 5: Model Predictions - Market Hours by Gender, Skill and Sector

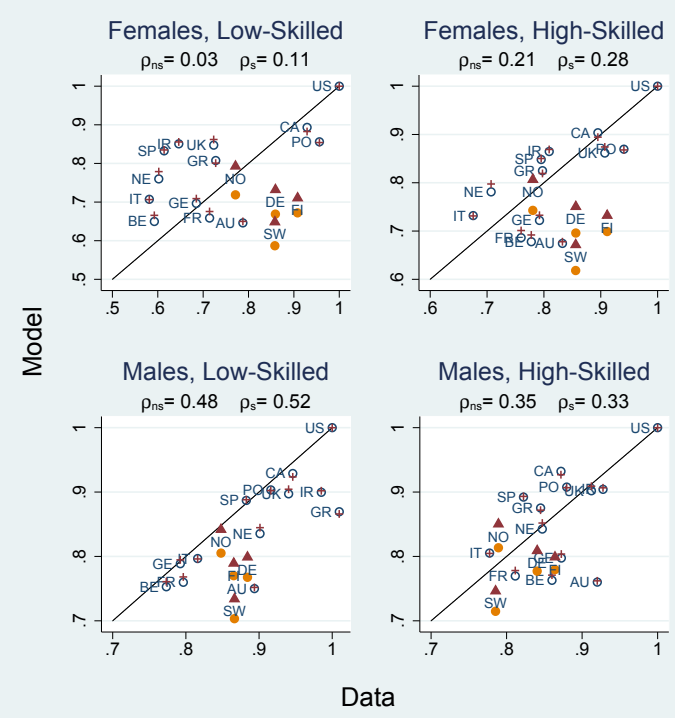

\begin{tabular}{|lll|}
\hline No Subsidy: & - Nordic & $\circ$ Other \\
Subsidy: & $\Delta$ Nordic & + Other $\quad$ 45-deg \\
\hline
\end{tabular}

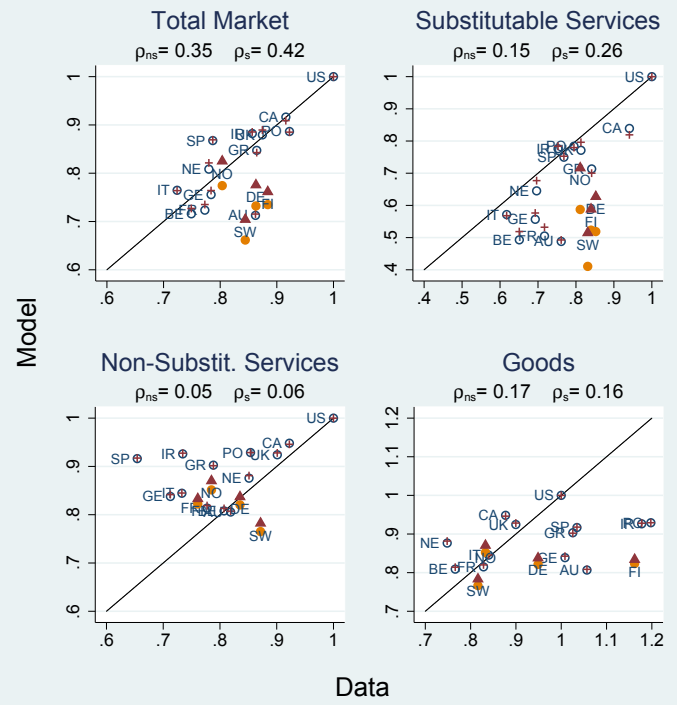

No Subsidy: Nordic o Other

Subsidy: $\quad$ Nordic + Other $\longrightarrow$ 45-deg

$\rho_{s}$ and $\rho_{n s}$ - Concordance correlation coefficient in models with and without subsidies, respectively. 


\section{Figure 6: Model Predictions - Marketization by Population Group}

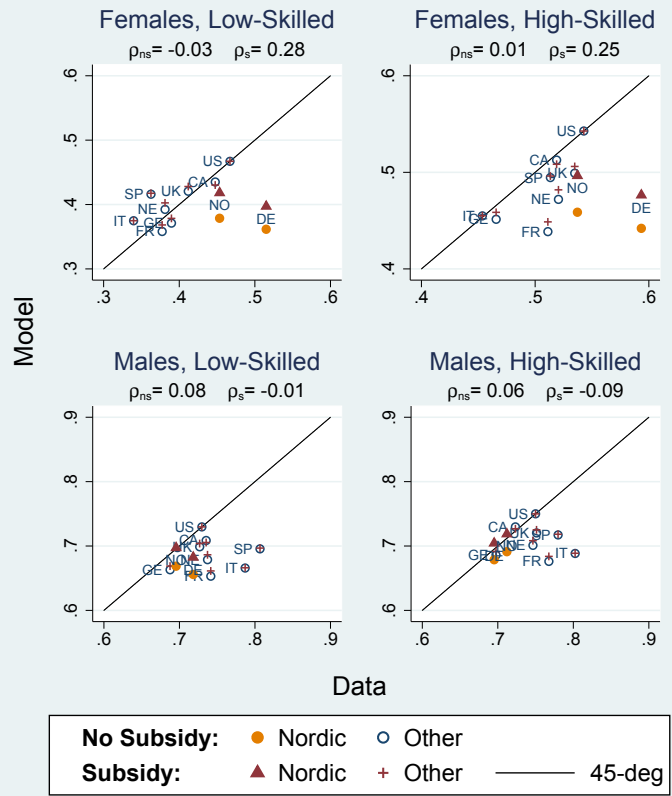

$\rho_{s}$ and $\rho_{n s}$ - Concordance correlation coefficient in models with and without subsidies, respectively.

Figure 7: Model Predictions - Total Work Share by Population Group

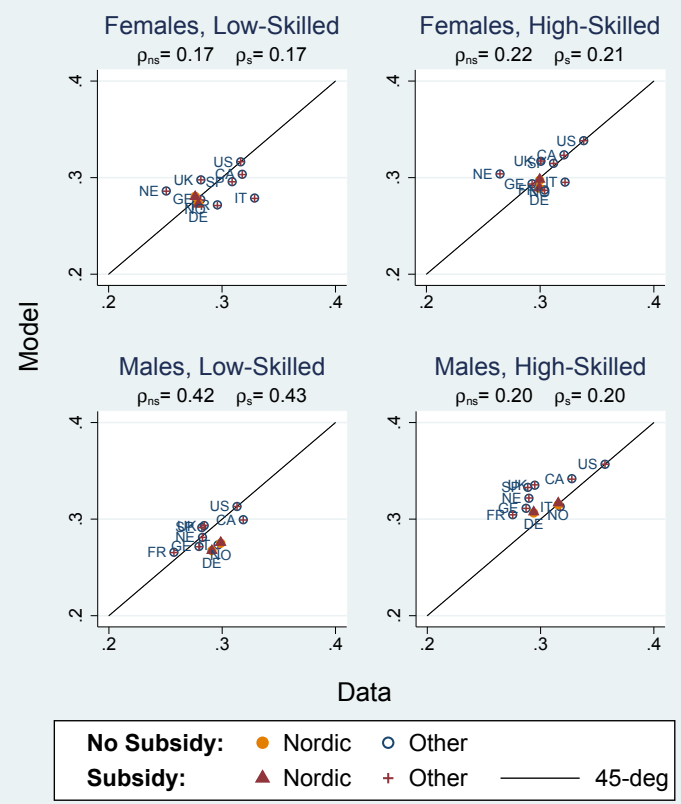

$\rho_{s}$ and $\rho_{n s}$ - Concordance correlation coefficient in models with and without subsidies, respectively. 


\section{Figure 8: Model Predictions - Gender Wage Ratio by Skill Group}

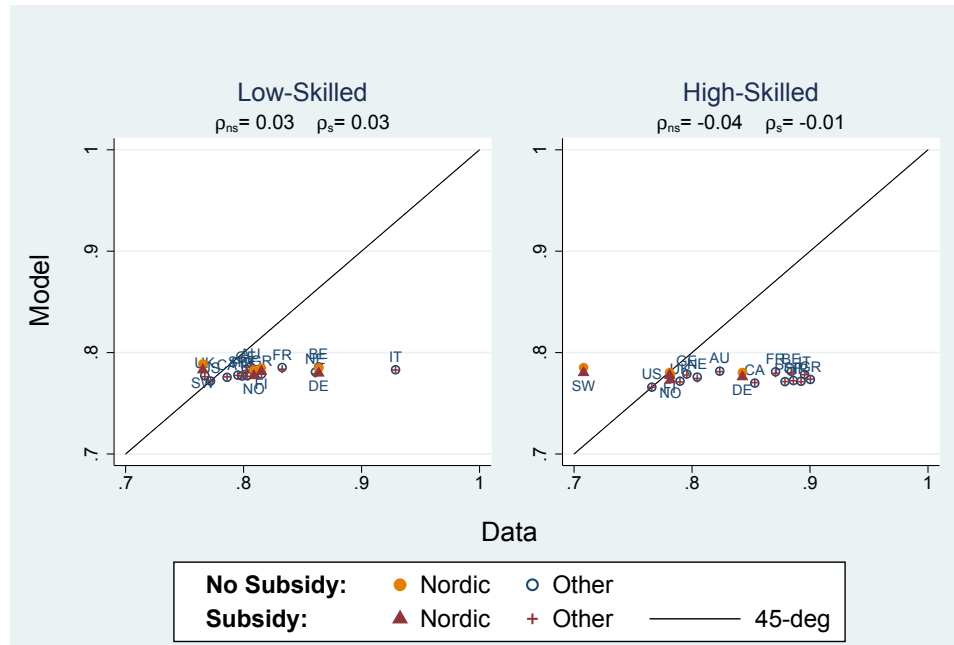

$\rho_{s}$ and $\rho_{n s}$ - Concordance correlation coefficient in models with and without subsidies, respectively. 


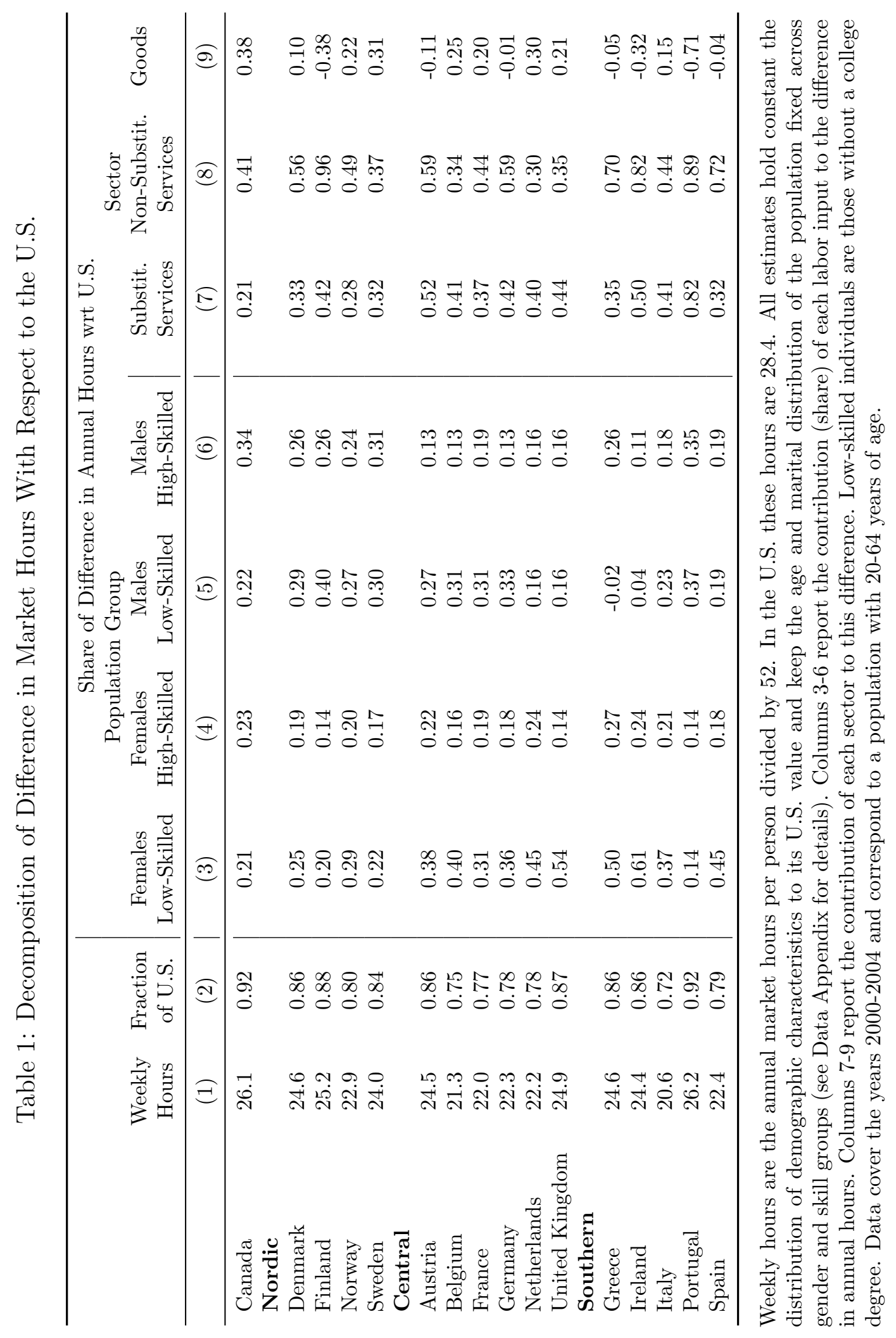




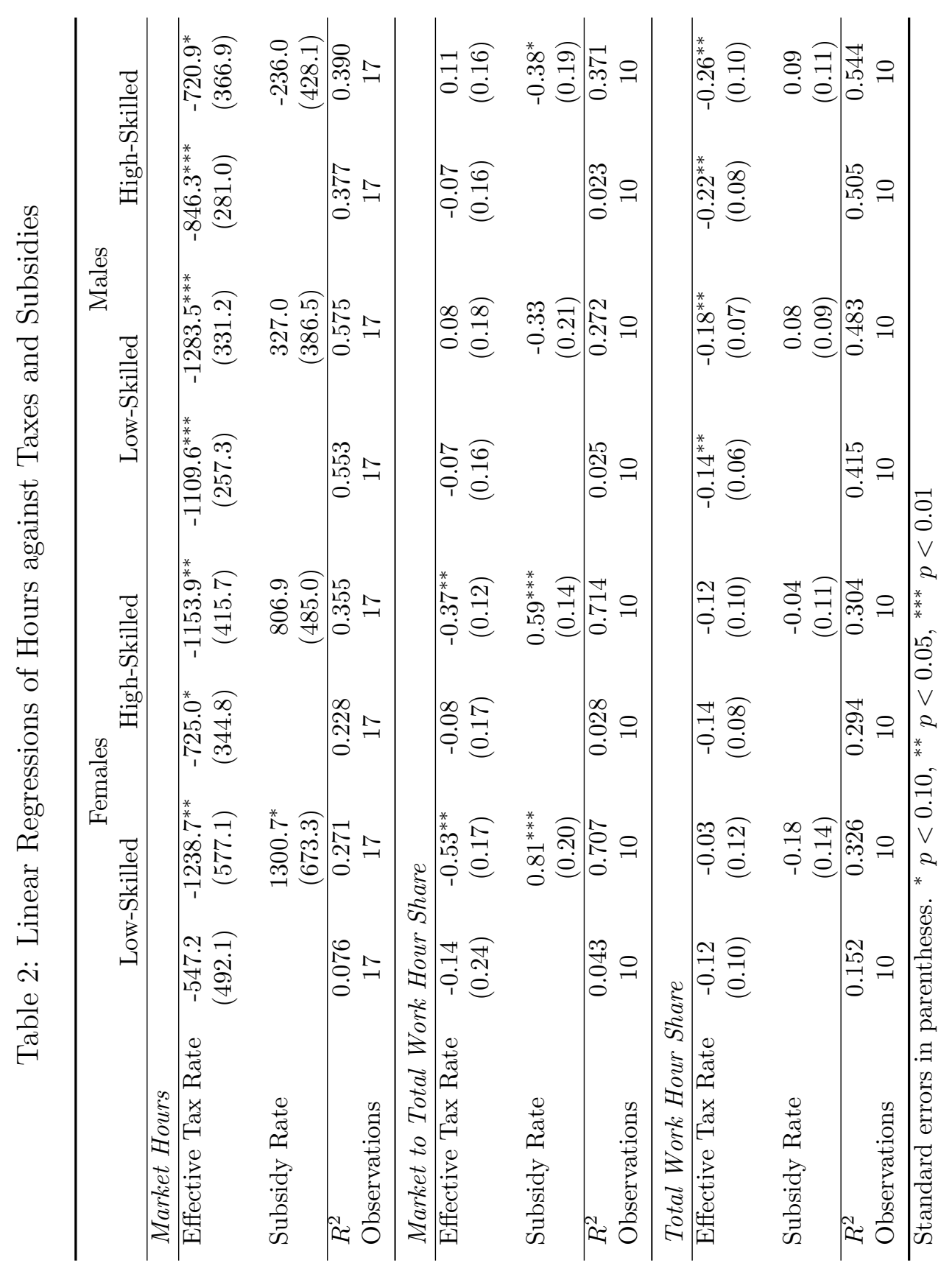




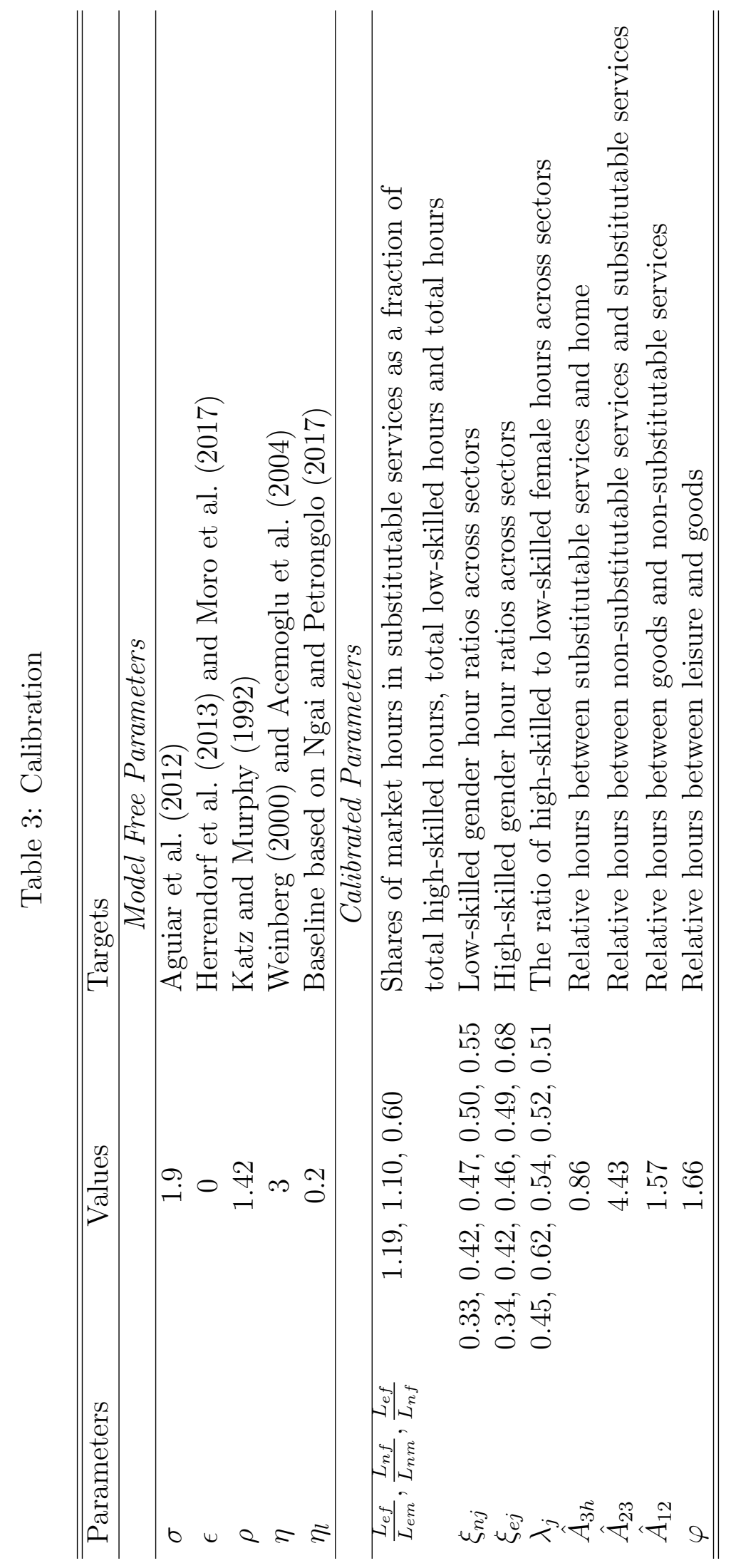


Table 4: Market Hours by Labor Input - Model without Subsidies

\begin{tabular}{|c|c|c|c|c|c|c|c|c|}
\hline & \multicolumn{4}{|c|}{ Females } & \multicolumn{4}{|c|}{ Males } \\
\hline & \multicolumn{2}{|c|}{ Low-Skilled } & \multicolumn{2}{|c|}{ High-Skilled } & \multicolumn{2}{|c|}{ Low-Skilled } & \multicolumn{2}{|c|}{ High-Skilled } \\
\hline & Data & Model & Data & Model & Data & Model & Data & Model \\
\hline Canada & -0.07 & -0.11 & -0.11 & -0.10 & -0.05 & -0.07 & -0.13 & -0.07 \\
\hline \multicolumn{9}{|l|}{ Nordic } \\
\hline Denmark & -0.14 & -0.33 & -0.14 & -0.30 & -0.12 & -0.23 & -0.16 & -0.22 \\
\hline Finland & -0.09 & -0.33 & -0.09 & -0.30 & -0.13 & -0.23 & -0.14 & -0.22 \\
\hline Norway & -0.23 & -0.28 & -0.22 & -0.26 & -0.15 & -0.19 & -0.21 & -0.19 \\
\hline Sweden & -0.14 & -0.41 & -0.14 & -0.38 & -0.13 & -0.30 & -0.21 & -0.29 \\
\hline Average Nordic & -0.15 & -0.34 & -0.15 & -0.31 & -0.13 & -0.24 & -0.18 & -0.23 \\
\hline \multicolumn{9}{|l|}{ Central } \\
\hline Austria & -0.21 & -0.35 & -0.17 & -0.33 & -0.11 & -0.25 & -0.08 & -0.24 \\
\hline Belgium & -0.41 & -0.35 & -0.22 & -0.32 & -0.23 & -0.25 & -0.14 & -0.24 \\
\hline France & -0.29 & -0.34 & -0.24 & -0.31 & -0.20 & -0.24 & -0.19 & -0.23 \\
\hline Germany & -0.32 & -0.30 & -0.21 & -0.28 & -0.21 & -0.21 & -0.13 & -0.20 \\
\hline Netherlands & -0.40 & -0.24 & -0.29 & -0.22 & -0.10 & -0.16 & -0.15 & -0.16 \\
\hline United Kingdom & -0.28 & -0.15 & -0.09 & -0.14 & -0.06 & -0.10 & -0.09 & -0.10 \\
\hline $\begin{array}{l}\text { Average Central } \\
\text { Southern }\end{array}$ & \multicolumn{7}{|c|}{ Southern } & -0.19 \\
\hline Greece & -0.27 & -0.19 & -0.20 & -0.18 & 0.01 & -0.13 & -0.16 & -0.12 \\
\hline Ireland & -0.35 & -0.15 & -0.19 & -0.14 & -0.01 & -0.10 & -0.07 & -0.10 \\
\hline Italy & -0.42 & -0.29 & -0.32 & -0.27 & -0.18 & -0.20 & -0.22 & -0.19 \\
\hline Portugal & -0.04 & -0.14 & -0.06 & -0.13 & -0.08 & -0.10 & -0.12 & -0.09 \\
\hline Spain & -0.39 & -0.17 & -0.20 & -0.15 & -0.12 & -0.11 & -0.18 & -0.11 \\
\hline Average Southern & -0.29 & -0.19 & -0.20 & -0.17 & -0.08 & -0.13 & -0.15 & -0.12 \\
\hline Concord. Corr. & & 0.03 & & 0.21 & & 0.48 & & 0.35 \\
\hline Correlation & & 0.04 & & 0.26 & & 0.68 & & 0.41 \\
\hline
\end{tabular}

All values are expressed as a percentage difference of the U.S. value. "Concord. Corr" represents the concordance correlation. "Correlation" represents the usual correlation coefficient. 
Table 5: Market Hours by Sector - Model without Subsidies

\begin{tabular}{|c|c|c|c|c|c|c|c|c|}
\hline & \multicolumn{2}{|c|}{ Total Market } & \multicolumn{2}{|c|}{$\begin{array}{l}\text { Substitutable } \\
\text { Service }\end{array}$} & \multicolumn{2}{|c|}{$\begin{array}{c}\text { Non-Substitutable } \\
\text { Service }\end{array}$} & \multicolumn{2}{|c|}{ Goods } \\
\hline & Data & Model & Data & Model & Data & Model & Data & Model \\
\hline Canada & -0.08 & -0.08 & -0.06 & -0.16 & -0.08 & -0.05 & -0.12 & -0.05 \\
\hline \multicolumn{9}{|l|}{ Nordic } \\
\hline Denmark & -0.14 & -0.27 & -0.15 & -0.48 & -0.16 & -0.18 & -0.05 & -0.18 \\
\hline Finland & -0.12 & -0.27 & -0.16 & -0.48 & -0.24 & -0.18 & 0.16 & -0.18 \\
\hline Norway & -0.20 & -0.23 & -0.19 & -0.41 & -0.22 & -0.15 & -0.17 & -0.15 \\
\hline Sweden & -0.16 & -0.34 & -0.17 & -0.59 & -0.13 & -0.23 & -0.18 & -0.23 \\
\hline Average Nordic & -0.15 & -0.27 & -0.17 & -0.49 & -0.19 & -0.19 & -0.06 & -0.18 \\
\hline \multicolumn{9}{|l|}{ Central } \\
\hline Austria & -0.14 & -0.29 & -0.24 & -0.51 & -0.18 & -0.19 & 0.06 & -0.19 \\
\hline Belgium & -0.25 & -0.28 & -0.35 & -0.51 & -0.19 & -0.19 & -0.23 & -0.19 \\
\hline France & -0.23 & -0.28 & -0.28 & -0.50 & -0.22 & -0.19 & -0.17 & -0.19 \\
\hline Germany & -0.22 & -0.24 & -0.31 & -0.44 & -0.29 & -0.16 & 0.01 & -0.16 \\
\hline Netherlands & -0.22 & -0.19 & -0.30 & -0.35 & -0.15 & -0.12 & -0.25 & -0.12 \\
\hline United Kingdom & -0.13 & -0.12 & -0.19 & -0.23 & -0.10 & -0.08 & -0.10 & -0.08 \\
\hline \multicolumn{8}{|l|}{ Southern } & -0.15 \\
\hline Greece & -0.14 & -0.15 & -0.16 & -0.29 & -0.21 & -0.10 & 0.03 & -0.10 \\
\hline Ireland & -0.14 & -0.12 & -0.25 & -0.22 & -0.27 & -0.07 & 0.18 & -0.07 \\
\hline Italy & -0.28 & -0.24 & -0.38 & -0.43 & -0.27 & -0.16 & -0.16 & -0.15 \\
\hline Portugal & -0.08 & -0.11 & -0.21 & -0.22 & -0.15 & -0.07 & 0.20 & -0.07 \\
\hline Spain & -0.21 & -0.13 & -0.23 & -0.25 & -0.35 & -0.08 & 0.03 & -0.08 \\
\hline Average Southern & -0.17 & -0.15 & -0.25 & -0.28 & -0.25 & -0.10 & 0.06 & -0.10 \\
\hline Concord. Corr. & & 0.35 & & 0.15 & & 0.05 & & 0.17 \\
\hline Correlation & & 0.42 & & 0.33 & & 0.08 & & 0.35 \\
\hline
\end{tabular}

All values are expressed as a percentage difference of the U.S. value. "Concord. Corr" represents the concordance correlation. "Correlation" represents the usual correlation coefficient. 
Table 6: Market Hours by Labor Input - Model with Subsidies

\begin{tabular}{|c|c|c|c|c|c|c|c|c|}
\hline & \multicolumn{4}{|c|}{ Females } & \multicolumn{4}{|c|}{ Males } \\
\hline & \multicolumn{2}{|c|}{ Low-Skilled } & \multicolumn{2}{|c|}{ High-Skilled } & \multicolumn{2}{|c|}{ Low-Skilled } & \multicolumn{2}{|c|}{ High-Skilled } \\
\hline & Data & Model & Data & Model & Data & Model & Data & Model \\
\hline Canada & -0.07 & -0.12 & -0.11 & -0.11 & -0.05 & -0.08 & -0.13 & -0.07 \\
\hline Nordic & & & & & & & & \\
\hline Denmark & -0.14 & -0.27 & -0.14 & -0.25 & -0.12 & -0.20 & -0.16 & -0.19 \\
\hline Finland & -0.09 & -0.29 & -0.09 & -0.27 & -0.13 & -0.21 & -0.14 & -0.20 \\
\hline Norway & -0.23 & -0.21 & -0.22 & -0.19 & -0.15 & -0.16 & -0.21 & -0.15 \\
\hline Sweden & -0.14 & -0.35 & -0.14 & -0.33 & -0.13 & -0.27 & -0.21 & -0.25 \\
\hline Average Nordic & -0.15 & -0.28 & -0.15 & -0.26 & -0.13 & -0.21 & -0.18 & -0.20 \\
\hline Central & & & & & & & & \\
\hline Austria & -0.21 & -0.35 & -0.17 & -0.32 & -0.11 & -0.25 & -0.08 & -0.24 \\
\hline Belgium & -0.41 & -0.33 & -0.22 & -0.31 & -0.23 & -0.24 & -0.14 & -0.23 \\
\hline France & -0.29 & -0.32 & -0.24 & -0.30 & -0.20 & -0.23 & -0.19 & -0.22 \\
\hline Germany & -0.32 & -0.29 & -0.21 & -0.27 & -0.21 & -0.21 & -0.13 & -0.20 \\
\hline Netherlands & -0.40 & -0.22 & -0.29 & -0.20 & -0.10 & -0.16 & -0.15 & -0.15 \\
\hline United Kingdom & -0.28 & -0.14 & -0.09 & -0.13 & -0.06 & -0.10 & -0.09 & -0.09 \\
\hline $\begin{array}{l}\text { Average Central } \\
\text { Southern }\end{array}$ & -0.32 & -0.28 & -0.20 & -0.25 & -0.15 & -0.20 & -0.13 & -0.19 \\
\hline Greece & -0.27 & -0.20 & -0.20 & -0.18 & 0.01 & -0.13 & -0.16 & -0.13 \\
\hline Ireland & -0.35 & -0.14 & -0.19 & -0.13 & -0.01 & -0.10 & -0.07 & -0.09 \\
\hline Italy & -0.42 & -0.29 & -0.32 & -0.27 & -0.18 & -0.20 & -0.22 & -0.20 \\
\hline Portugal & -0.04 & -0.15 & -0.06 & -0.13 & -0.08 & -0.10 & -0.12 & -0.09 \\
\hline Spain & -0.39 & -0.17 & -0.20 & -0.15 & -0.12 & -0.11 & -0.18 & -0.11 \\
\hline Average Southern & -0.29 & -0.19 & -0.20 & -0.17 & -0.08 & -0.13 & -0.15 & -0.12 \\
\hline Concord. Corr. & & 0.11 & & 0.28 & & 0.52 & & 0.33 \\
\hline Correlation & & 0.12 & & 0.32 & & 0.69 & & 0.36 \\
\hline
\end{tabular}

All values are expressed as a percentage difference of the U.S. value. "Concord. Corr" represents the concordance correlation. "Correlation" represents the usual correlation coefficient. 
Table 7: Market Hours by Sector - Model with Subsidies

\begin{tabular}{|c|c|c|c|c|c|c|c|c|}
\hline & \multicolumn{2}{|c|}{ Total Market } & \multicolumn{2}{|c|}{$\begin{array}{l}\text { Substitutable } \\
\text { Service }\end{array}$} & \multicolumn{2}{|c|}{$\begin{array}{c}\text { Non-Substitutable } \\
\text { Service }\end{array}$} & \multicolumn{2}{|c|}{ Goods } \\
\hline & Data & Model & Data & Model & Data & Model & Data & Model \\
\hline Canada & -0.08 & -0.09 & -0.06 & -0.18 & -0.08 & -0.05 & -0.12 & -0.05 \\
\hline \multicolumn{9}{|l|}{ Nordic } \\
\hline Denmark & -0.14 & -0.22 & -0.15 & -0.37 & -0.16 & -0.16 & -0.05 & -0.16 \\
\hline Finland & -0.12 & -0.24 & -0.16 & -0.41 & -0.24 & -0.17 & 0.16 & -0.17 \\
\hline Norway & -0.20 & -0.18 & -0.19 & -0.28 & -0.22 & -0.13 & -0.17 & -0.13 \\
\hline Sweden & -0.16 & -0.30 & -0.17 & -0.49 & -0.13 & -0.22 & -0.18 & -0.22 \\
\hline Average Nordic & -0.15 & -0.23 & -0.17 & -0.39 & -0.19 & -0.17 & -0.06 & -0.17 \\
\hline \multicolumn{9}{|l|}{ Central } \\
\hline Austria & -0.14 & -0.28 & -0.24 & -0.51 & -0.18 & -0.19 & 0.06 & -0.19 \\
\hline Belgium & -0.25 & -0.27 & -0.35 & -0.48 & -0.19 & -0.19 & -0.23 & -0.19 \\
\hline France & -0.23 & -0.26 & -0.28 & -0.47 & -0.22 & -0.18 & -0.17 & -0.18 \\
\hline Germany & -0.22 & -0.24 & -0.31 & -0.42 & -0.29 & -0.16 & 0.01 & -0.16 \\
\hline Netherlands & -0.22 & -0.18 & -0.30 & -0.32 & -0.15 & -0.12 & -0.25 & -0.12 \\
\hline United Kingdom & -0.13 & -0.11 & -0.19 & -0.20 & -0.10 & -0.07 & -0.10 & -0.07 \\
\hline \multicolumn{8}{|l|}{ Southern } & -0.15 \\
\hline Greece & -0.14 & -0.16 & -0.16 & -0.30 & -0.21 & -0.10 & 0.03 & -0.10 \\
\hline Ireland & -0.14 & -0.11 & -0.25 & -0.22 & -0.27 & -0.07 & 0.18 & -0.07 \\
\hline Italy & -0.28 & -0.24 & -0.38 & -0.43 & -0.27 & -0.16 & -0.16 & -0.15 \\
\hline Portugal & -0.08 & -0.11 & -0.21 & -0.22 & -0.15 & -0.07 & 0.20 & -0.07 \\
\hline Spain & -0.21 & -0.13 & -0.23 & -0.25 & -0.35 & -0.08 & 0.03 & -0.08 \\
\hline Average Southern & -0.17 & -0.15 & -0.25 & -0.28 & -0.25 & -0.10 & 0.06 & -0.10 \\
\hline Concord. Corr. & & 0.42 & & 0.26 & & 0.06 & & 0.16 \\
\hline Correlation & & 0.46 & & 0.47 & & 0.10 & & 0.33 \\
\hline
\end{tabular}

All values are expressed as a percentage difference of the U.S. value. "Concord. Corr" represents the concordance correlation. "Correlation" represents the usual correlation coefficient. 
Table 8: Marketization - Market Work as Share of Total Work

\begin{tabular}{|c|c|c|c|c|c|c|c|c|}
\hline & \multicolumn{4}{|c|}{ Females } & \multicolumn{4}{|c|}{ Males } \\
\hline & \multicolumn{2}{|c|}{ Low-Skilled } & \multicolumn{2}{|c|}{ High-Skilled } & \multicolumn{2}{|c|}{ Low-Skilled } & \multicolumn{2}{|c|}{ High-Skilled } \\
\hline & Data & Model & Data & Model & Data & Model & Data & Model \\
\hline \multicolumn{9}{|l|}{ No Subsidies } \\
\hline Canada & -0.02 & -0.03 & -0.02 & -0.03 & 0.01 & -0.02 & -0.03 & -0.02 \\
\hline \multicolumn{9}{|l|}{ Nordic } \\
\hline Denmark & 0.05 & -0.11 & 0.05 & -0.10 & -0.01 & -0.07 & -0.05 & -0.07 \\
\hline Norway & -0.01 & -0.09 & -0.01 & -0.08 & -0.03 & -0.06 & -0.04 & -0.06 \\
\hline Average Nordic & 0.02 & -0.10 & 0.02 & -0.09 & -0.02 & -0.07 & -0.05 & -0.06 \\
\hline \multicolumn{9}{|l|}{ Central } \\
\hline France & -0.09 & -0.11 & -0.03 & -0.10 & 0.01 & -0.08 & 0.02 & -0.07 \\
\hline Germany & -0.08 & -0.10 & -0.08 & -0.09 & -0.04 & -0.07 & -0.05 & -0.06 \\
\hline Netherlands & -0.09 & -0.07 & -0.02 & -0.07 & 0.01 & -0.05 & 0.00 & -0.05 \\
\hline United Kingdom & -0.06 & -0.05 & -0.01 & -0.04 & 0.00 & -0.03 & 0.00 & -0.03 \\
\hline \multicolumn{4}{|l|}{ Southern } & -0.08 & -0.01 & -0.06 & -0.01 & -0.05 \\
\hline Italy & -0.13 & -0.09 & -0.09 & -0.09 & 0.06 & -0.06 & 0.05 & -0.06 \\
\hline Spain & -0.10 & -0.05 & -0.03 & -0.05 & 0.08 & -0.03 & 0.03 & -0.03 \\
\hline Average Southern & -0.12 & -0.07 & -0.06 & -0.07 & 0.07 & -0.05 & 0.04 & -0.05 \\
\hline Concord. Corr. & & -0.03 & & 0.01 & & 0.08 & & 0.06 \\
\hline Correlation & & -0.04 & & 0.03 & & 0.29 & & 0.15 \\
\hline \multicolumn{9}{|l|}{ With Subsidies } \\
\hline Canada & -0.02 & -0.04 & -0.02 & -0.03 & 0.01 & -0.02 & -0.03 & -0.02 \\
\hline \multicolumn{9}{|l|}{ Nordic } \\
\hline Denmark & 0.05 & -0.07 & 0.05 & -0.07 & -0.01 & -0.05 & -0.05 & -0.05 \\
\hline Norway & -0.01 & -0.05 & -0.01 & -0.05 & -0.03 & -0.03 & -0.04 & -0.03 \\
\hline Average Nordic & 0.02 & -0.06 & 0.02 & -0.06 & -0.02 & -0.04 & -0.05 & -0.04 \\
\hline \multicolumn{9}{|l|}{ Central } \\
\hline France & -0.09 & -0.10 & -0.03 & -0.09 & 0.01 & -0.07 & 0.02 & -0.07 \\
\hline Germany & -0.08 & -0.09 & -0.08 & -0.08 & -0.04 & -0.06 & -0.05 & -0.06 \\
\hline Netherlands & -0.09 & -0.06 & -0.02 & -0.06 & 0.01 & -0.04 & 0.00 & -0.04 \\
\hline United Kingdom & -0.06 & -0.04 & -0.01 & -0.04 & 0.00 & -0.03 & 0.00 & -0.02 \\
\hline Average Central & -0.08 & -0.07 & -0.03 & -0.07 & -0.01 & -0.05 & -0.01 & -0.05 \\
\hline \multicolumn{9}{|l|}{ Southern } \\
\hline Italy & -0.13 & -0.09 & -0.09 & -0.09 & 0.06 & -0.06 & 0.05 & -0.06 \\
\hline Spain & -0.10 & -0.05 & -0.03 & -0.05 & 0.08 & -0.03 & 0.03 & -0.03 \\
\hline Average Southern & -0.12 & -0.07 & -0.06 & -0.07 & 0.07 & -0.05 & 0.04 & -0.05 \\
\hline Concord. Corr. & & 0.28 & & 0.25 & & -0.01 & & -0.09 \\
\hline Correlation & & 0.39 & & 0.46 & & -0.02 & & -0.20 \\
\hline
\end{tabular}

Marketization is measured by the share of market hours out of total work (market plus home). All values are expressed as a difference of the U.S. value. "Concord. Corr" represents the concordance correlation. "Correlation" represents the usual correlation coefficient. 
Table 9: Work vs Leisure - Total Work as Share of Total Time

\begin{tabular}{|c|c|c|c|c|c|c|c|c|}
\hline & \multicolumn{4}{|c|}{ Females } & \multicolumn{4}{|c|}{ Males } \\
\hline & \multicolumn{2}{|c|}{ Low-Skilled } & \multicolumn{2}{|c|}{ High-Skilled } & \multicolumn{2}{|c|}{ Low-Skilled } & \multicolumn{2}{|c|}{ High-Skilled } \\
\hline & Data & Model & Data & Model & Data & Model & Data & Model \\
\hline \multicolumn{9}{|l|}{ No Subsidies } \\
\hline Canada & 0.001 & -0.01 & -0.02 & -0.01 & 0.01 & -0.01 & -0.03 & -0.02 \\
\hline \multicolumn{9}{|l|}{ Nordic } \\
\hline Denmark & -0.04 & -0.04 & -0.04 & -0.05 & -0.02 & -0.05 & -0.06 & -0.05 \\
\hline Norway & -0.04 & -0.04 & -0.04 & -0.04 & -0.01 & -0.04 & -0.04 & -0.04 \\
\hline Average Nordic & -0.04 & -0.04 & -0.04 & -0.05 & -0.02 & -0.04 & -0.05 & -0.05 \\
\hline \multicolumn{9}{|l|}{ Central } \\
\hline France & -0.02 & -0.04 & -0.03 & -0.05 & -0.06 & -0.05 & -0.08 & -0.05 \\
\hline Germany & -0.04 & -0.04 & -0.05 & -0.04 & -0.03 & -0.04 & -0.07 & -0.05 \\
\hline Netherlands & -0.07 & -0.03 & -0.07 & -0.03 & -0.03 & -0.03 & -0.07 & -0.04 \\
\hline United Kingdom & -0.04 & -0.02 & -0.04 & -0.02 & -0.03 & -0.02 & -0.06 & -0.02 \\
\hline $\begin{array}{l}\text { Average Central } \\
\text { Southern }\end{array}$ & \multicolumn{7}{|c|}{ Southern } & -0.04 \\
\hline Italy & 0.01 & -0.04 & -0.02 & -0.04 & -0.02 & -0.04 & -0.04 & -0.04 \\
\hline Spain & -0.01 & -0.02 & -0.03 & -0.02 & -0.03 & -0.02 & -0.07 & -0.02 \\
\hline Average Southern & 0.00 & -0.03 & -0.02 & -0.03 & -0.02 & -0.03 & -0.05 & -0.03 \\
\hline Concord. Corr. & & 0.17 & & 0.22 & & 0.42 & & 0.20 \\
\hline Corr & & 0.23 & & 0.23 & & 0.51 & & 0.40 \\
\hline \multicolumn{9}{|l|}{ With Subsidies } \\
\hline Canada & 0.001 & -0.01 & -0.02 & -0.02 & 0.01 & -0.01 & -0.03 & -0.02 \\
\hline Nordic & & & & & & & & \\
\hline Denmark & -0.04 & -0.04 & -0.04 & -0.05 & -0.02 & -0.05 & -0.06 & -0.05 \\
\hline Norway & -0.04 & -0.04 & -0.04 & -0.04 & -0.01 & -0.04 & -0.04 & -0.04 \\
\hline Average Nordic & -0.04 & -0.04 & -0.04 & -0.04 & -0.02 & -0.04 & -0.05 & -0.04 \\
\hline \multicolumn{9}{|l|}{ Central } \\
\hline $\begin{array}{l}\text { France } \\
\text { Germany }\end{array}$ & -0.02 & -0.05 & -0.03 & -0.05 & -0.06 & -0.05 & -0.08 & $\begin{array}{r}-0.05 \\
0.05\end{array}$ \\
\hline Germany & -0.04 & -0.04 & -0.05 & -0.04 & -0.03 & -0.04 & -0.07 & $\begin{array}{r}-0.05 \\
-0.03\end{array}$ \\
\hline Netherlands & -0.07 & -0.03 & -0.07 & -0.03 & -0.03 & -0.03 & -0.07 & -0.03 \\
\hline United Kingdom & -0.04 & -0.02 & -0.04 & -0.02 & -0.03 & -0.02 & -0.06 & -0.02 \\
\hline $\begin{array}{l}\text { Average Central } \\
\text { Southern }\end{array}$ & -0.04 & -0.03 & -0.05 & -0.04 & -0.04 & -0.04 & -0.07 & -0.04 \\
\hline Italy & 0.01 & -0.04 & -0.02 & -0.04 & -0.02 & -0.04 & -0.04 & -0.04 \\
\hline Spain & -0.01 & -0.02 & -0.03 & -0.02 & -0.03 & -0.02 & -0.07 & -0.02 \\
\hline Average Southern & 0.00 & -0.03 & -0.02 & -0.03 & -0.02 & -0.03 & -0.05 & -0.03 \\
\hline Concord. Corr. & & 0.17 & & 0.21 & & 0.43 & & 0.20 \\
\hline Correlation & & 0.22 & & 0.22 & & 0.52 & & 0.41 \\
\hline
\end{tabular}

All values are expressed as a difference of the U.S. value. "Concord. Corr" represents the concordance correlation. "Correlation" represents the usual correlation coefficient. 
Table 10: Gender Wage Ratio by Skill

\begin{tabular}{|c|c|c|c|c|c|c|c|c|}
\hline & \multicolumn{4}{|c|}{ No Subsidies } & \multicolumn{4}{|c|}{ Subsidies Included } \\
\hline & \multicolumn{2}{|c|}{ Low Skilled } & \multicolumn{2}{|c|}{ High Skilled } & \multicolumn{2}{|c|}{ Low Skilled } & \multicolumn{2}{|c|}{ High Skilled } \\
\hline & Data & Model & Data & Model & Data & Model & Data & Model \\
\hline Canada & 0.014 & 0.004 & 0.087 & 0.004 & 0.014 & 0.004 & 0.087 & 0.005 \\
\hline \multicolumn{9}{|l|}{ Nordic } \\
\hline Denmark & 0.092 & 0.013 & 0.077 & 0.015 & 0.092 & 0.008 & 0.077 & 0.010 \\
\hline Finland & 0.043 & 0.013 & 0.015 & 0.014 & 0.043 & 0.009 & 0.015 & 0.012 \\
\hline Norway & 0.037 & 0.011 & 0.016 & 0.012 & 0.037 & 0.005 & 0.016 & 0.007 \\
\hline Sweden & -0.007 & 0.017 & -0.058 & 0.019 & -0.007 & 0.011 & -0.058 & 0.014 \\
\hline Average Nordic & 0.041 & 0.013 & 0.012 & 0.015 & 0.041 & 0.008 & 0.012 & 0.011 \\
\hline \multicolumn{9}{|l|}{ Central } \\
\hline Austria & 0.034 & 0.014 & 0.058 & 0.016 & 0.034 & 0.013 & 0.058 & 0.015 \\
\hline Belgium & 0.092 & 0.014 & 0.118 & 0.016 & 0.092 & 0.012 & 0.118 & 0.014 \\
\hline France & 0.061 & 0.013 & 0.105 & 0.015 & 0.061 & 0.012 & 0.105 & 0.014 \\
\hline Germany & 0.030 & 0.012 & 0.030 & 0.013 & 0.030 & 0.010 & 0.030 & 0.012 \\
\hline Netherlands & 0.089 & 0.009 & 0.038 & 0.010 & 0.089 & 0.007 & 0.038 & 0.009 \\
\hline United Kingdom & -0.005 & 0.005 & 0.024 & 0.006 & -0.005 & 0.004 & 0.024 & 0.005 \\
\hline Average Central & 0.050 & 0.011 & 0.062 & 0.013 & 0.050 & 0.010 & 0.062 & 0.011 \\
\hline \multicolumn{9}{|l|}{ Southern } \\
\hline Greece & 0.043 & 0.007 & 0.134 & 0.008 & 0.043 & 0.007 & 0.134 & 0.008 \\
\hline Ireland & 0.031 & 0.005 & 0.127 & 0.006 & 0.031 & 0.005 & 0.127 & 0.005 \\
\hline Italy & 0.157 & 0.011 & 0.130 & 0.013 & 0.157 & 0.011 & 0.130 & 0.012 \\
\hline Portugal & 0.027 & 0.005 & 0.113 & 0.006 & 0.027 & 0.005 & 0.113 & 0.006 \\
\hline Spain & 0.023 & 0.006 & 0.120 & 0.007 & 0.023 & 0.006 & 0.120 & 0.006 \\
\hline Average Southern & 0.056 & 0.007 & 0.125 & 0.008 & 0.056 & 0.007 & 0.125 & 0.007 \\
\hline Concord. Col & & 0.03 & & -0.04 & & 0.03 & & -0.01 \\
\hline Correlation & & 0.27 & & -0.46 & & 0.38 & & -0.24 \\
\hline
\end{tabular}

All values are expressed as a difference of the U.S. value. "Concord. Corr" represents the concordance correlation. "Correlation" represents the usual correlation coefficient. 


\section{Data Appendix}

\section{A Hours of Work in the Market}

To analyze the hours of work in the market we use the European Union Labor Force Survey (EU-LFS) (Eurostat 2015), the March (ASEC) CPS for the United States (Flood, King, Ruggles and Warren 2015), and the 2001 Population Census for Canada (Minnesota Population Center 2017). Our sample is restricted to individuals between the age of 20-64. We classify individuals as high-skilled if they completed college. ${ }^{22}$

The EU-LFS contains information on weekly hours worked both in the main and in a secondary job. In order to construct a consistent measure of annual hours of work per person, we follow the procedures outlined by Bick et al. (2016), including the use of their estimated weeks of effective work over a calendar year. In the case of Finland and Canada, we scale up the weekly hours to match the aggregate annual hours as reported by the OECD, since the aforementioned paper does not include these countries in their sample. From the March CPS we estimate annual hours for the U.S. using information on weekly hours and the number of weeks worked in the previous calendar year. These estimates are then scaled to match the aggregate annual hours reported by Bick et al. (2016), who constructed their estimates using weekly hours from the CPS ORG samples and external information on the number of weeks worked.

To control for demographic differences across countries, we partition each country's population according to skill, gender, age (nine 5-year groups), and marital status. As a result, there are 72 population groups for each year/country pair. For each one of the population groups we calculate average hours and we aggregate them at the gender-skill level using as weights the U.S. population shares. Prior to the aggregation, we adjust the U.S. population shares to ensure that the distribution of age and marital status is constant across gender-skill groups. This is done as follows.

Denote by $g$ a member of the 72-group partition. For any given $g$, there is a corresponding gender-skill group $G S_{k}$ such that $g \in G S_{k}$, and a corresponding age-marital status group $A M_{l}$ such that $g \in A M_{l}$. Let $f(g), f\left(G S_{k}\right)$ and $f\left(A M_{l}\right)$ be the fraction of the population in these groups respectively. Then $f(g)$ can be rewritten as:

$$
f(g)=f\left(G S_{k}\right) f\left(A M_{l} \mid G S_{k}\right)
$$

where $f\left(A M_{l} \mid G S_{k}\right)$ is the fraction of group $G S_{k}$ with age-marital status $A M_{l}$. This fraction

\footnotetext{
${ }^{22}$ Olivetti and Petrongolo (2014) find that high-school dropouts and high-school graduates are equivalent labor inputs based on their average wages.
} 
$f\left(A M_{l} \mid G S_{k}\right)$ varies depending on the gender-skill group. To hold constant the distribution of age and marital status across different gender-skill groups, we replace $f\left(A M_{l} \mid G S_{k}\right)$ by $f\left(A M_{l}\right)$. This gives the weights to aggregate the 72 groups:

$$
\tilde{f}(g)=f\left(G S_{k}\right) f\left(A M_{l}\right)
$$

The weight $\tilde{f}(g)$ is constructed from the U.S. population and is then applied to all countries to estimate average hours that control for differences in the demographic composition of the population.

Table A1 presents evidence on the importance of the demographic adjustment. The first column reports the weekly market hours per person for each country before any adjustment for demographics. ${ }^{23}$ Following equation (A.2), we construct the adjusted hours for the U.S. holding constant the age and marital status composition across gender-skill groups. The difference between the adjusted values and the raw hours for the U.S. is reported at the bottom of the second column. The small difference, 0.02, implies that the compositional differences in age and marital status across gender-skill groups have almost no effect on the aggregate hours in the United States. The values in the second column for countries other than the U.S. are the differences between the raw hours in the first column and the adjusted U.S. hours.

The third column reports the percentage of the cross-country differences accounted for by differences in the composition of the population. This composition effect is estimated as follows. The average hours in a country $c, \bar{h}_{c}$, can be expressed as a weighted average of the average hours of different demographic groups, i.e. $\bar{h}_{c}=f_{c}(g)^{\prime} \bar{h}_{c}(g)$, where $f_{c}(g)$ is the vector of population group shares in country $c$, and $\bar{h}_{c}(g)$ is the vector of group-specific average hours. The average hours in the U.S. holding the age and marital status composition constant across gender-skill groups is $\tilde{\bar{h}}_{U S}=\tilde{f}_{U S}(g)^{\prime} \bar{h}_{U S}(g)$, where $\tilde{f}_{U S}(g)$ is the vector of population group shares in equation (A.2). We can express the difference in average hours relative to the adjusted U.S. value as:

$$
\tilde{\bar{h}}_{U S}-\bar{h}_{c}=\tilde{f}_{U S}(g)^{\prime}\left(\bar{h}_{U S}(g)-\bar{h}_{c}(g)\right)+\left(\tilde{f}_{U S}(g)-f_{c}(g)\right)^{\prime} \bar{h}_{c}(g) .
$$

The second term in the right-hand side of the equation is the contribution of demographic differences to the overall hour gap. Column 3 shows that depending on the country, demographic differences account for between 2 and 33 percent of the cross-country difference in hours.

Table A2 reports market hours after adjusting in addition for compositional differences

\footnotetext{
${ }^{23}$ The weekly hours are equal to annual market hours per person divided by 52 .
} 
due to the presence of small children (age 5 or less) in the household. ${ }^{24}$ The table shows that the hours obtained are very similar to the ones when the presence of small children is ignored in the demographic adjustment.

\section{A.1 Sectoral Hours}

The detailed sectoral classification is presented in Table A3. Given the available industry classification in most household surveys, a more detailed disaggregation is not possible. ${ }^{25}$ Sectoral hours are estimated by multiplying the average market hours per person with the share of hours in a given sector. To be consistent with the previous estimates, we also hold the demographics constant across countries in constructing the sectoral hour shares. The procedure is as follows.

Denote by $P$ the total population in a given country, let $p(g)$ be the population size of group $g$, denote by $p(s, g)$ the number of persons in group $g$ employed in sector $s$, and let $\bar{h}(s, g)$ be their average hours of work. As before, let $\bar{h}(g)$ be the average market hours per person in group $g$, and denote by $H$ and $H_{s}$ the total number of hours worked in the economy, and in sector $s$, respectively. The sectoral share of hours can be expressed as:

$$
\begin{aligned}
\nu_{s} & =\frac{H_{s}}{H} \\
& =\frac{\sum_{g} p(s, g) \bar{h}(s, g)}{\sum_{g} p(g) \bar{h}(g)} \\
& =\frac{\sum_{g} \frac{p(s, g)}{p(g)} \frac{p(g)}{P} \bar{h}(s, g)}{\sum_{g} \frac{p(g)}{P} \bar{h}(g)} \\
& =\frac{\sum_{g} f(s \mid g) f(g) \bar{h}(s, g)}{\sum_{g} f(g) \bar{h}(g)},
\end{aligned}
$$

where $f(s \mid g)=\frac{p(s, g)}{p(g)}$ is the fraction of group $g$ who works in sector $s$, and $f(g)=\frac{p(g)}{P}$ is the population share of group $g$. To estimate the sectoral shares holding constant the demographics of the population at the U.S. level, we can replace $f(g)$ in the above equation with $\tilde{f}_{U S}(g)$ from equation (A.2):

$$
\hat{\nu}_{s}=\frac{\sum_{g} f(s \mid g) \tilde{f}_{U S}(g) \bar{h}(s, g)}{\sum_{g} \tilde{f}_{U S}(g) \bar{h}(g)} .
$$

\footnotetext{
${ }^{24}$ This adjustment is not made for Nordic countries nor Canada due to the lack of data.

${ }^{25}$ EU-LFS do not separate wholesale trade with retail trade. We assign the hours going to "Retail Trade" by using detailed hours information from the EU-KLEMS database (see Timmer, O'Mahony and van Ark (2007)), and in the case of France and the UK, by using the national versions of their labor surveys.
} 
Since the EU-LFS reports hours at the main and secondary job, and these jobs can be in different sectors, the above procedure needs to be adjusted to handle this type of information. This additional adjustment does not change the main logic of the above procedure, hence we include its details in the Online Appendix.

In addition, in Table A6 we report the participation shares of different population groups in each sector, for different regions.

\section{B Time Use Data}

The time use classification used in this paper follows closely the one of Aguiar and Hurst (2007b) with a few minor adjustments. First, our market hours correspond to the total market work in Aguiar and Hurst (2007b). Second, our home hours is the sum of total nonmarket work and child care time in Aguiar and Hurst (2007b). Third, we assign time spent on gardening and caring for pets to leisure while Aguiar and Hurst (2007b) include it in both home hours and leisure.

\section{Taxes and Subsidies}

The labor income and consumption taxes $\left(\tau, t_{j}\right)$ are from McDaniel (2007). Labor income taxes include Federal and State income taxes, as well as Social Security taxes. We use the average rates for the period of 2000-04, except for Ireland and Greece, where, for data availability reasons, we use data from 2002-04, and 2005, respectively.

The expenditures on "in-kind" social subsidies, $S$, are obtained from the OECD Social Expenditure Database (SOCX). The SOCX includes Old-Age, Incapacity, and Family benefits. The "in-kind" expenditures $S$ are the non-cash public benefits in these three categories, and include expenditures on residential care, home-help services, rehabilitation, and early childhood education and care (e.g. day-care and pre-school services) (see Adema et al. (2011) for a description of the SOCX database).

The subsidy rate $s$ is given by:

$$
s=\frac{S}{G O_{S S}}
$$

where $G O_{S S}$ is the gross output in the substitutable service sector. $G O_{S S}$ is constructed using the WIOD input-output matrices (see Timmer, Dietzenbacher, Los, Stehrer and de Vries (2015)). As in Prescott (2004), the effective tax rate is:

$$
\tau_{e}=\frac{t_{j}+\tau}{1+t_{j}}
$$


The net consumption tax in the substitutable service sector is $t_{3}=t_{1}-s$. The resulting tax and subsidy rates are reported in Table A4. In this table we also show the detailed components that make up the social subsidy. ${ }^{26}$

\section{Wages}

We construct hourly wage rates using the Labor Force Surveys for France and the UK (Insee 2014, ONS 2015), the Socioeconomic Panel (SOEP) for Germany (Socio-Economic Panel (SOEP) 2015, Wagner, Frick and Schupp 2007), the 2001 population Census for Canada, and the March CPS for the United States. For the rest of Europe, we use the European Community Household Panel (ECHP) (Eurostat 2003) for 2000-2001, and the European Union Statistics on Income and Living Conditions (EU-SILC) (Eurostat 2014) for 2003$2004 .^{27}$ In all cases, wages are estimated using the earnings of employees only.

Most surveys provide a measure of current monthly earnings, which is converted to hourly wages by dividing by the product of 4.33 and the weekly hours of work. However, monthly earnings are not available for the U.S. and some countries in SILC, in which case hourly wages are constructed using earnings from the previous year. ${ }^{28}$ For the U.S., we divide the previous year earnings by the product of usual weekly hours and weeks worked in that year. For the SILC countries, we divide the previous year earnings by the product of the number of months worked in that year and the current number of weekly hours $\times 4.33$, because the number of weekly hours worked in the previous year are not available. For this reason, we exclude individuals who changed jobs between the income reference period and the time of the interview.

Gender wage ratios are estimated controlling for age and marital status through a standard Mincerian regression. More specifically, we regress log-wages on a second-order age polynomial, a marital status dummy, and interacted dichotomous indicators for college and gender. $^{29}$ The predicted gender wage ratios are obtained by taking the exponent of the corresponding skill-gender interaction parameters.

\footnotetext{
${ }^{26}$ The SOCX database does not report the Incapacity care expenditures in Canada and the U.S., and the expenditures on Old-Age care in Canada. We impute these missing components by assuming that their share out of the total care expenditures equals the average shares (for each respective component) in countries with complete data. Similar results are obtained by assuming these components equal zero.

${ }^{27}$ The EU-LFS does not contain detailed earnings information.

${ }^{28}$ In SILC these countries include Belgium, Denmark, Finland, The Netherlands, Norway, and Sweden.

${ }^{29}$ Each regression is estimated separately by country. More precisely, for each survey we pool the data for years 2000-4, and include year fixed effects in the estimations whenever more than one year is pooled. In the case of the ECHP and SILC surveys, we estimate separate regressions for each survey-country pair, and the estimated wage gaps are then averaged together. In all cases, the regressions are estimated using the surveys' sampling weights.
} 


\section{E Care Usage and Subsidies}

Table A5 displays the correlations between formal care use measures and the different subcomponents of the social subsidy. By formal care we mean the care occurring in an institutional setting outside home or paid care at home.

For children aged 0-5 we estimate the average weekly hours of formal care per child using the European Union Statistics on Income and Living Conditions, EU-SILC, for European

countries and the National Survey of America's Families (NSAF) 2002 for the United States (Urban Institute 2002). For the older population (age 65 or more) we obtain the fraction of the population in formal long-term care (excluding the population in hospitals). Finally, we also obtain the fraction of the total population in long-term care (including younger individuals in incapacity care). 
Table A1: Contribution of Demographics to Differences in Hours With the U.S.

\begin{tabular}{|c|c|c|c|}
\hline & $\begin{array}{l}\text { Raw Effective } \\
\text { Weekly Hours }\end{array}$ & $\begin{array}{l}\text { Market Hours } \\
\text { Difference wrt } \\
\text { adjusted U.S. }\end{array}$ & $\begin{array}{c}\text { Composition } \\
\text { Effect }(\%)\end{array}$ \\
\hline & (1) & $(2)$ & $(3)$ \\
\hline Canada & 25.9 & 2.5 & 5.5 \\
\hline \multicolumn{4}{|l|}{ Nordic } \\
\hline Denmark & 24.1 & 4.3 & 10.2 \\
\hline Finland & 24.2 & 4.2 & 21.6 \\
\hline Norway & 22.7 & 5.7 & 2.0 \\
\hline Sweden & 23.7 & 4.8 & 7.6 \\
\hline \multicolumn{4}{|l|}{ Central } \\
\hline Austria & 22.9 & 5.6 & 29.5 \\
\hline Belgium & 20.2 & 8.3 & 13.7 \\
\hline France & 21.0 & 7.4 & 13.0 \\
\hline Germany & 20.6 & 7.8 & 21.2 \\
\hline Netherlands & 21.6 & 6.8 & 8.2 \\
\hline United Kingdom & 23.8 & 4.6 & 23.0 \\
\hline \multicolumn{4}{|l|}{ Southern } \\
\hline Greece & 23.4 & 5.0 & 23.1 \\
\hline Ireland & 23.9 & 4.5 & 9.7 \\
\hline Italy & 18.8 & 9.6 & 18.5 \\
\hline Portugal & 25.1 & 3.3 & 33.4 \\
\hline Spain & 21.3 & 7.1 & 15.1 \\
\hline United States & 28.4 & 0.02 & 100 \\
\hline
\end{tabular}

The raw effective weekly hours are the annual market hours per person divided by 52 , without adjusting for demographic differences between countries. Column (2) is the difference between column (1) and the hours in the U.S. obtained after holding constant the age and marital composition across skill-gender groups. The composition effect in column (3) is the percentage of the value in column (2) due to demographic differences relative to the U.S. (see equation (A.3)). Data cover individuals aged 20-64 years, over the years 2000-2004. 
Table A2: Market Hours by Population Group Adjusting for Compositional Differences in Age, Marital Status, and Presence of Small Children

\begin{tabular}{|c|c|c|c|c|c|c|c|c|}
\hline & \multicolumn{4}{|c|}{ Females } & \multicolumn{4}{|c|}{ Males } \\
\hline & \multicolumn{2}{|c|}{ Low-Skilled } & \multicolumn{2}{|c|}{ High-Skilled } & \multicolumn{2}{|c|}{ Low-Skilled } & \multicolumn{2}{|c|}{ High-Skilled } \\
\hline & Hours & abs(\% Diff) & Hours & $\operatorname{abs}(\%$ Diff $)$ & Hours & $\operatorname{abs}(\%$ Diff $)$ & Hours & abs(\% Diff) \\
\hline \multicolumn{9}{|l|}{ Central } \\
\hline Austria & 17.2 & 0.60 & 22.4 & 1.77 & 28.1 & 0.33 & 33.4 & 0.55 \\
\hline Belgium & 12.9 & 0.71 & 20.9 & 1.63 & 24.2 & 0.26 & 31.7 & 2.28 \\
\hline France & 15.9 & 1.39 & 21.0 & 0.98 & 25.0 & 0.00 & 29.4 & 0.41 \\
\hline Germany & 14.9 & 1.23 & 21.2 & 2.06 & 25.0 & 0.62 & 31.6 & 0.38 \\
\hline Netherlands & 13.3 & 0.41 & 19.0 & 1.51 & 28.3 & 0.18 & 30.8 & 0.86 \\
\hline United Kingdom & 16.4 & 2.98 & 24.5 & 1.44 & 29.6 & 0.18 & 33.1 & 0.53 \\
\hline \multicolumn{9}{|l|}{ Southern } \\
\hline Greece & 15.9 & 0.73 & 21.6 & 0.84 & 31.9 & 0.78 & 30.8 & 0.88 \\
\hline Ireland & 14.8 & 3.83 & 22.2 & 0.51 & 30.9 & 0.06 & 33.5 & 0.13 \\
\hline Italy & 12.7 & 0.78 & 18.4 & 0.20 & 25.7 & 0.35 & 28.2 & 0.48 \\
\hline Portugal & 21.0 & 0.08 & 25.3 & 1.49 & 28.8 & 0.04 & 31.8 & 0.12 \\
\hline Spain & 13.4 & 0.54 & 21.5 & 1.06 & 27.7 & 0.19 & 29.9 & 0.83 \\
\hline United States & 22.0 & 0.14 & 27.3 & 0.34 & 31.4 & 0.03 & 36.1 & 0.08 \\
\hline Concordance Corr. & 0.997 & & 0.993 & & 0.999 & & 0.992 & \\
\hline
\end{tabular}

Columns "Hours" report weekly market hours holding constant the population composition by age, marital status, and presence of small children (age 5 or less). Columns abs(\% Diff) report the absolute percentage difference between the reported hours and the ones without adjustment for the presence of small children. The last row reports the concordance correlation for the hours with and without adjustment for the presence of small children.

Table A3: Sector Classification

\begin{tabular}{ll}
\hline Sector & ISIC (v. 3) Code \\
\hline Goods & Agriculture, Hunting, Forestry and Fishing (A,B) \\
& Mining and Quarrying \\
& Manufacturing (D) \\
& Electricity, Gas, and Water (E) \\
& Construction (F) \\
& \\
Non-Substitutable Services & Wholesale Trade and Sale of Motor vehicles (50,51) \\
& Transport and Communications (I) \\
& Financial Intermediation (J) \\
& Real Estate and Business Activities (K) \\
& Public Administration, Defense, Compulsory Soc. Sec. (L) \\
& Education (M) \\
& Retail Trade (52) \\
& Hotels and Restaurants (H) \\
Substitutable Services & Health and Social Work (N) \\
& Other Personal and Community Services (O) \\
& Private Households as Employers (P) \\
\hline
\end{tabular}


Table A4: Taxes and Subsidies

\begin{tabular}{lcccccc}
\hline & \multicolumn{2}{c}{ Taxes } & \multicolumn{4}{c}{ Subsidies on Care } \\
\cline { 4 - 7 } & Income & Consumption & Old-Age & Incapacity & Family & Total \\
\hline Canada & 0.22 & 0.17 & 0.003 & 0.003 & 0.007 & 0.01 \\
Nordic & & & & & & \\
Denmark & 0.33 & 0.31 & 0.070 & 0.046 & 0.081 & 0.20 \\
Finland & 0.37 & 0.23 & 0.038 & 0.036 & 0.056 & 0.13 \\
Norway & 0.32 & 0.25 & 0.096 & 0.042 & 0.058 & 0.20 \\
Sweden & 0.41 & 0.32 & 0.099 & 0.064 & 0.062 & 0.22 \\
Average Nordic & 0.36 & 0.28 & 0.076 & 0.047 & 0.064 & 0.19 \\
Central & & & & & & \\
Austria & 0.40 & 0.21 & 0.015 & 0.012 & 0.017 & 0.04 \\
Belgium & 0.41 & 0.20 & 0.006 & 0.033 & 0.037 & 0.08 \\
France & 0.38 & 0.23 & 0.010 & 0.007 & 0.062 & 0.08 \\
Germany & 0.39 & 0.15 & 0.000 & 0.029 & 0.030 & 0.06 \\
Netherlands & 0.32 & 0.18 & 0.028 & 0.009 & 0.035 & 0.07 \\
United Kingdom & 0.26 & 0.17 & 0.017 & 0.011 & 0.031 & 0.06 \\
Average Central & 0.36 & 0.19 & 0.013 & 0.017 & 0.036 & 0.07 \\
Southern & & & & & & \\
Greece & 0.30 & 0.15 & 0.002 & 0.002 & 0.013 & 0.02 \\
Ireland & 0.22 & 0.23 & 0.015 & 0.004 & 0.023 & 0.04 \\
Italy & 0.35 & 0.20 & 0.003 & 0.002 & 0.025 & 0.03 \\
Portugal & 0.24 & 0.18 & 0.005 & 0.002 & 0.021 & 0.03 \\
Spain & 0.28 & 0.15 & 0.009 & 0.005 & 0.021 & 0.04 \\
Average Southern & 0.28 & 0.18 & 0.007 & 0.003 & 0.021 & 0.03 \\
\hline United States & 0.21 & 0.07 & 0.001 & 0.006 & 0.022 & 0.03 \\
\hline
\end{tabular}

Labor income and consumption taxes are obtained from McDaniel (2007). Subsidies are constructed following Ngai and Pissarides (2011), and are expressed as fraction of the Gross Output of the Substitutable Service sector. Incapacity care subsidy is imputed for the U.S. and Canada, while Old-Age care expenditures are imputed for Canada. For more details see section $\mathrm{C}$ in this Appendix.

Table A5: Correlations of Formal Care Use and Subsidies

\begin{tabular}{lcccc}
\hline & \multirow{2}{*}{$\begin{array}{c}\text { Avg. Hours } \\
\text { Subsidy Rates }\end{array}$} & \multicolumn{2}{c}{$\%$ in Long-Term Care } \\
\cline { 4 - 4 } & Child Care & Old & All Ages \\
\hline Family & 0.64 & & \\
Old & & 0.65 & 0.65 \\
Old \& Incapacity & & & 0.65 \\
\hline
\end{tabular}

Correlations exclude Canada due to data availability reasons. Childcare hours are for children aged 0-5 and include hours spent on early education. The \% in LTC at all ages is for Austria, Greece, France, Ireland, Portugal, Spain, and the United Kingdom. 
Table A6: Sector Participation Shares by Population Group

\begin{tabular}{lcccc}
\hline & & & \multicolumn{2}{c}{ Services } \\
\cline { 5 - 5 } & Not Employed & Goods & Non-Substitutable & Substitutable \\
\hline Females, Low-Skilled & & & & \\
$\quad$ North America & 31.8 & 10.5 & 26.0 & 31.7 \\
$\quad$ Nordic & 29.3 & 11.6 & 25.1 & 34.0 \\
Central & 39.6 & 10.3 & 23.7 & 26.5 \\
$\quad$ Southern & 49.8 & 13.6 & 16.3 & 20.3 \\
Average & 37.6 & 11.5 & 22.8 & 28.1 \\
Females, High-Skilled & & & & \\
$\quad$ North America & 20.4 & 6.5 & 44.3 & 28.8 \\
$\quad$ Nordic & 17.2 & 7.1 & 38.7 & 37.0 \\
Central & 22.2 & 6.4 & 42.4 & 29.0 \\
$\quad$ Southern & 25.3 & 5.5 & 47.1 & 22.1 \\
Average & 21.3 & 6.4 & 43.1 & 29.2 \\
Males, Low-Skilled & & & & \\
$\quad$ North America & 19.2 & 34.4 & 28.2 & 18.2 \\
Nordic & 19.8 & 38.3 & 28.3 & 13.7 \\
Central & 23.2 & 35.0 & 28.5 & 13.3 \\
$\quad$ Southern & 21.9 & 41.2 & 22.0 & 14.8 \\
Average & 21.0 & 37.2 & 26.8 & 15.0 \\
Males, High-Skilled & & & & \\
$\quad$ North America & 12.9 & 18.5 & 49.9 & 18.7 \\
$\quad$ Nordic & 13.5 & 20.1 & 50.1 & 16.2 \\
Central & 14.0 & 22.5 & 46.6 & 16.8 \\
$\quad$ Southern & 13.7 & 19.1 & 49.3 & 17.9 \\
Average & 13.5 & 20.1 & 49.0 & 17.4 \\
\hline
\end{tabular}

Shares are adjusted for demographic differences across countries. Low-skilled individuals are those without a college degree. Data cover years 2000-2004. 